\title{
Facile fabrication and enhanced photocatalytic performance of visible light responsive UiO-66- $\mathrm{NH}_{2} / \mathrm{Ag}_{2} \mathrm{CO}_{3}$ composite
}

\author{
Yun-Cai Zhou, Xue-Yan Xu, Peng Wang, Huifen Fu, Chen Zhao, Chong-Chen Wang * \\ Beijing Key Laboratory of Functional Materials for Building Structure and Environment Remediation, Beijing University of Civil Engineering and \\ Architecture, Beijing 100044, China
}

\section{A R T I C L E I N F O}

Article history:

Received 1 May 2019

Accepted 26 June 2019

Published 5 December 2019

\section{Keywords:}

Metal-organic framework

$\mathrm{Ag}_{2} \mathrm{CO}_{3}$

Hexavalent chromium

Photocatalytic

Reaction mechanism

\begin{abstract}
A B S T R A C T
A series of $\mathrm{UiO}-66-\mathrm{NH}_{2} / \mathrm{Ag}_{2} \mathrm{CO}_{3}$ Z-scheme heterojunctions were prepared by a simple ion-exchange-solution method using $\mathrm{UiO}-66-\mathrm{NH}_{2}$ and semiconductor $\mathrm{Ag}_{2} \mathrm{CO}_{3}$ as precursors. The photocatalytic activities of UAC- $X$ (UAC-20, 50, 100, 150, 200) Z-scheme heterojunctions toward the hexavalent chromium ( $\mathrm{Cr}(\mathrm{VI})$ ) reduction and UAC-100 toward oxidative degradation of four organic dyes like rhodamine B (RhB), methyl orange (MO), congo red (CR), and methylene blue (MB) under visible light irradiation were investigated. The effects of different $\mathrm{pH}(\mathrm{pH}=2,3,4,6,8)$, small organic acids (citric acid, tartaric acid, and oxalic acid), and foreign ions (ions in tap water and surface water) on $\mathrm{Cr}(\mathrm{VI})$ reduction were explored. The results revealed that the UAC-100 heterojunctions displayed more remarkable $\mathrm{Cr}(\mathrm{VI})$ reduction performance than the pristine $\mathrm{UiO}-66-\mathrm{NH}_{2}$ and $\mathrm{Ag}_{2} \mathrm{CO}_{3}$, resulting from the improved separation of photo-induced electrons and holes. The enhanced photocatalytic activity of UAC-100 was further confirmed by the photoluminescence measurement, electrochemical analysis, and active species trapping experiments. After four cycles' experiments, the photocatalytic Cr(VI) reduction efficiency over UAC-100 was still over 99\%, which exhibited that UAC-100 had excellent reusability and stability. Finally, the corresponding photocatalytic reaction mechanism was proposed and tested.
\end{abstract}

(C) 2019, Dalian Institute of Chemical Physics, Chinese Academy of Sciences. Published by Elsevier B.V. All rights reserved.

\section{Introduction}

As a consequence of economic development, population growth, urbanization, and infrastructural development, the ecological environment is undergoing great stress due to the discharge of wastewater containing heavy metals and organic pollutants [1]. Among various heavy metal ions, hexavalent chromium $\mathrm{Cr}(\mathrm{VI})$, as a mutagenic and carcinogenic pollutant, was widely spreading surface water and groundwater [2-4]. Up to now, some methods like ion exchange [5,6], adsorption [7], membrane separation [8], electrocoagulation [9], and photocatalytic reduction [10] have been developed to remove $\mathrm{Cr}(\mathrm{VI})$ from wastewater. In all the above methods, photocatalytic reduction transformation from $\mathrm{Cr}(\mathrm{VI})$ to $\mathrm{Cr}$ (III) is an effective method to remove $\mathrm{Cr}(\mathrm{VI})$ from wastewater, considering that $\mathrm{Cr}(\mathrm{III})$ is less toxic and was removed as the form of $\mathrm{Cr}(\mathrm{OH})_{3}$ in neutral or alkaline conditions [11]. Compared with traditional reduction methods like chemical reduction and electrochemical reduction [12], photocatalytic $\mathrm{Cr}(\mathrm{VI})$ reduction into $\mathrm{Cr}(\mathrm{III})$ exhibited the advantages like energy saving, high efficiency, and

\footnotetext{
* Corresponding author. Tel/Fax: +86-10-61209186; E-mail: wangchongchen@bucea.edu.cn

This work was supported by the National Natural Science Foundation of China (51878023, 51578034), Great Wall Scholars Training Program Project of Beijing Municipality Universities (CIT\&TCD20180323), Project of Construction of Innovation Teams and Teacher Career Development for Universities and Colleges Under Beijing Municipality (IDHT20170508), Beijing Talent Project (2018A35), and BUCEA Post Graduate Innovation Project (PG2019039).

DOI: S1872-2067(19)63433-9 | http://www.sciencedirect.com/science/journal/18722067 | Chin. J. Catal., Vol. 40, No. 12, December 2019
} 
free toxic by-product. Organic pollutants like organic dyes are not only toxic but also carcinogenic. Their chemical stability and hard degradation in nature will pose serious threats to human health and ecosystem sustainability. Numerous studies have shown that organic dye decomposition via a photocatalytic process is an efficient and practical solution [13-16]. In recent years, semiconductor photocatalysts have attracted wide attentions in solving global energy problems and environmental pollution [17-19]. Among various semiconductor photocatalysts, titanium dioxide $\left(\mathrm{TiO}_{2}\right)$ is widely used for pollutant removal with the aid of its advantages like toxicity free, high stability, and low cost [20-25]. However, the main disadvantage of $\mathrm{TiO}_{2}$ is its only UV light response due to its large band gap, which greatly limits the use of sunlight (only 2\%-3\% of sunlight) [26]. At present, $\mathrm{Ag}_{2} \mathrm{CO}_{3}$ with a narrow band gap has been found to demonstrate remarkably photocatalytic activity in the visible light region [16,26-30]. Previous research focused on fabrication of $\mathrm{Ag}_{2} \mathrm{CO}_{3}$ onto different substrates as composite photocatalysts for water treatment, such as $\mathrm{Ag}_{2} \mathrm{CO}_{3} / \mathrm{TiO}_{2}$ [26], $\mathrm{Ag}_{2} \mathrm{O} / \mathrm{Ag}_{2} \mathrm{CO}_{3}$ [27], and $\mathrm{Ag}_{2} \mathrm{CO}_{3} / \mathrm{UiO}-66(\mathrm{Zr})$ [16] along with $\mathrm{GO}-\mathrm{Ag}_{2} \mathrm{CO}_{3}$ [31], which displayed the superior photocatalytic activity to $\mathrm{Ag}_{2} \mathrm{CO}_{3}$ but still suffered from serious photo-corrosion. Therefore, the improvements in both stability and photocatalytic activity of $\mathrm{Ag}_{2} \mathrm{CO}_{3}$ are the two main objectives to be achieved in future.

In the last two decades, metal-organic frameworks (MOFs) have been widely utilized as efficient photocatalysts to conduct $\mathrm{CO}_{2}$ reduction [31-34], $\mathrm{H}_{2}$ evolution [34-36], $\mathrm{Cr}(\mathrm{VI})$ reduction $[2,13,17,37-41]$, and organic pollutant decomposition $[10,15,16,42-44]$ because of the ultrahigh adsorption capacity and efficient light utilization ability $[13,38,42,45]$. However, the pristine MOFs as photocatalysts exhibit a large band gap and can only be degraded by ultraviolet light, which will greatly reduce the utilization of solar energy. Up to now, numerous studies have focused on immobilizing other photocatalytically active semiconductors on MOFs substrates to extend the photo-responsive region to the visible region. For example, $\mathrm{Ag}_{2} \mathrm{CO}_{3}$ was attached to UiO-66 to construct a binary composite for visible-light-driven degradation of organic dyes [16]. Metal free g- $\mathrm{C}_{3} \mathrm{~N}_{4}$ was encapsulated on BUC-21 for photocatalytic reduction of $\mathrm{Cr}(\mathrm{VI})$ under simulated sunlight irradiation [39]. As well, MIL-53(Al) was decorated with g- $\mathrm{C}_{3} \mathrm{~N}_{4}$ for enhanced photocatalytic rhodamine $\mathrm{B}(\mathrm{RhB})$ decomposition under visible-light irradiation [46]. These studies demonstrated that MOFs/semiconductors composites exhibited increasing light utilization efficiency than the individual MOFs. Hence, MOFs can act as a perfect substrate to load a variety of semiconductor materials to form heterojunction for potential applications in water treatment. Among all MOF materials, UiO-66 as a zirconium-based three-dimensional MOF not only has the advantages of other MOFs, but also has excellent thermal stability and chemical stability $[47,48]$. In 2015 , Wu et al. [16] reported that UiO-66 (Zr) and $\mathrm{Ag}_{2} \mathrm{CO}_{3}$ are combined to enhance the visible light catalytic degradation of RhB. Zhang et al. [49] constructed the $\mathrm{Ag}_{3} \mathrm{PO}_{4} / \mathrm{UiO}-66$ heterojunction for efficient visible light degradation of $\mathrm{RhB}$. Our research group found that $\mathrm{UiO}-66-\mathrm{NH}_{2} / \mathrm{Ag}_{3} \mathrm{PO}_{4}$ and $\mathrm{UiO}-66-\mathrm{NH}_{2} / \mathrm{Ag}_{2} \mathrm{CO}_{3}$ composites ex- hibited effective capture and visible-triggered release toward sulfonamides due to the formation and split between $\mathrm{Ag}^{+}$and $-\mathrm{NH}_{2}$ group [50,51]. Up to now, there has been no report on the efficiently photocatalytic $\mathrm{Cr}(\mathrm{VI})$ reduction over UiO-66- $\mathrm{NH}_{2} / \mathrm{Ag}_{2} \mathrm{CO}_{3}$ composites under visible light illumination. With this paper, the UiO-66- $\mathrm{NH}_{2} / \mathrm{Ag}_{2} \mathrm{CO}_{3} \mathrm{Z}$-scheme heterojunction (UAC- $X$ Z-scheme heterojunction) is used to achieve photocatalytic $\mathrm{Cr}(\mathrm{VI})$ reduction under visible light irradiation. In addition, the stability of the UiO-66- $\mathrm{NH}_{2} / \mathrm{Ag}_{2} \mathrm{CO}_{3}$ heterojunction was investigated, and the photocatalytic mechanism was proposed and tested.

\section{Experimental}

\subsection{Materials and characterization}

All materials and reagents were commercially available and used directly without further purification. The characterization methods are listed in the Supporting Information.

\subsection{Preparation of UiO-66- $\mathrm{NH}_{2} / \mathrm{Ag}_{2} \mathrm{CO}_{3}$ composites}

The UiO-66- $\mathrm{NH}_{2}$ was hydrothermally synthesized as described in a previous report with slight modification [35]. Briefly, 2-aminoterephthalic acid ( $\mathrm{NH}_{2}$-BDC) ( $4.5 \mathrm{mmol}, 0.81 \mathrm{~g}$ ) was completely dissolved in $N, N^{\prime}$-dimethylformamide (DMF, 40 $\mathrm{mL}$ ) by ultrasound for ca. $10 \mathrm{~min}$. Then, $\mathrm{ZrCl}_{4}(4.5 \mathrm{mmol}, 1.05 \mathrm{~g}$ ) and acetic acid (HAc, $17 \mathrm{~mL}$ ) were added to this solution. All the above processes were carried out in a $100 \mathrm{~mL}$ Teflon-lined stainless-steel autoclave. HAc was added to tune the morphology of UiO-66- $\mathrm{NH}_{2}$. The autoclave was placed in a drying oven and heated at $120{ }^{\circ} \mathrm{C}$ for $24 \mathrm{~h}$. After cooling to room temperature, the product was centrifuged and cleaned several times with ultra-pure water. The prepared UiO-66- $\mathrm{NH}_{2}$ was dried at $60{ }^{\circ} \mathrm{C}$ in a drying oven before use.

UAC- $X$ composites (UAC-20, 50, 100, 150, 200) were fabricated by a simple ion-exchange-solution method with a small modification [16,50,51], as illustrated in Scheme 1. Taking UAC-100 (the weight ratio of UiO-66- $\mathrm{NH}_{2}$ and $\mathrm{Ag}_{2} \mathrm{CO}_{3}$ being 1:1) for an example, the $\mathrm{Na}_{2} \mathrm{CO}_{3}$ aqueous solution $(10 \mathrm{~mL}, 0.030$ $\mathrm{mol} / \mathrm{L})$ was added dropwise into the suspension $(100 \mathrm{~mL})$ of UiO-66- $\mathrm{NH}_{2}(1000 \mathrm{mg} / \mathrm{L})$ and $\mathrm{AgNO}_{3}(0.006 \mathrm{~mol} / \mathrm{L})$. The mixture was stirred vigorously with a magnetic stirrer for $3.5 \mathrm{~h}$.

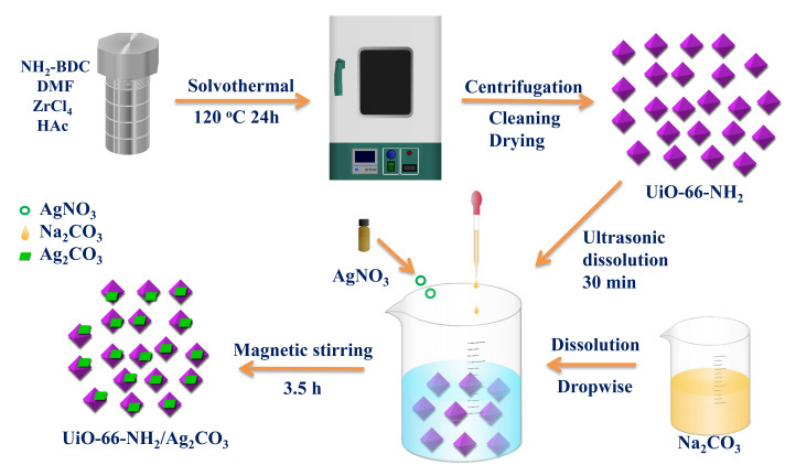

Scheme 1. Illustration of the fabrication of UiO- $66-\mathrm{NH}_{2} / \mathrm{Ag}_{2} \mathrm{CO}_{3}(\mathrm{UAC}-X)$ composites. 
The precipitates were separated from the solution via filtration and washed with ultra-pure water and EtOH several times. The other UiO-66- $\mathrm{NH}_{2} / \mathrm{Ag}_{2} \mathrm{CO}_{3}$ (UAC- $X$ ) composite samples were fabricated similarly to UAC-100. The weight proportions of UiO-66- $\mathrm{NH}_{2}$ and $\mathrm{AgNO}_{3}$ in UAC-20, UAC-50, UAC-150 and UAC-200 were $0.2: 1,0.5: 1,1.5: 1$, and 2:1, respectively. For the sake of comparison, $\mathrm{Ag}_{2} \mathrm{CO}_{3}$ particles were also synthesized following the same method as UAC-100 except without adding UiO-66- $\mathrm{NH}_{2}$.

\subsection{Adsorption-photocatalysis experiment}

The photocatalytic performance of UAC- $X$ composites toward $\mathrm{Cr}(\mathrm{VI})$ reduction and organic pollutant degradation was investigated under visible light irradiation at ambient temperature. The photocatalytic $\mathrm{Cr}(\mathrm{VI})$ reduction experiment was carried out in a $50 \mathrm{~mL}$ quartz glass vessel containing $10 \mathrm{mg}$ UAC- $X$ composites (or individual UiO-66- $\mathrm{NH}_{2}$ and $\mathrm{Ag}_{2} \mathrm{CO}_{3}$ ) and $40 \mathrm{~mL} \mathrm{Cr}(\mathrm{VI})$ solution $(10 \mathrm{mg} / \mathrm{L})$. It is worth noting that the $\mathrm{pH}$ of $\mathrm{Cr}(\mathrm{VI})$ solution was adjusted to 2.0 with $\mathrm{H}_{2} \mathrm{SO}_{4}$ solution. The suspension was first magnetically stirred in the dark for $45 \mathrm{~min}$ to achieve adsorption-desorption equilibrium. Afterwards, the Cr(VI) solution was irradiated with 5.00 W LED (PCX50A, Beijing perfect light technology Co., LTD) for $60 \mathrm{~min}$, and the spectrum of light source (longer than $420 \mathrm{~nm}$ ) is shown in Fig. S1. At specific time interval, $1.5 \mathrm{~mL}$ liquor was drawn and filtered through $0.45 \mu \mathrm{m}$ syringe filter for analysis. The residual $\mathrm{Cr}(\mathrm{VI})$ was determined by a diphenylcarbazide (DPC) method via an
Auto Analyzer 3 (Seal, Germany). The operation flow and video of Auto Analyzer 3 are shown in Fig. S2. Blank experiments were also carried out under the identical conditions with no photocatalyst addition.

\section{Results and discussion}

\subsection{Characterization}

The FTIR spectra of $\mathrm{Ag}_{2} \mathrm{CO}_{3}$, UiO-66- $\mathrm{NH}_{2}$, and UAC- $X$ composites (Fig. 1a) revealed that the adsorption peaks at 1581.92 and $1382.09 \mathrm{~cm}^{-1}$ were assigned to the carboxylic functional groups in the $\mathrm{BDC}-\mathrm{NH}_{2}$ ligands, and the peaks between $600-800 \mathrm{~cm}^{-1}$ were ascribed to $\mathrm{Zr}-\mathrm{O}_{2}$ as vertical and horizontal mode scaling [52,53]. The peaks at 1374.62 and $803.06 \mathrm{~cm}^{-1}$ were attributed to the characteristic peaks for $\mathrm{CO}_{3}{ }^{2-}$ [46]. The characteristic adsorption peaks of UiO-66- $\mathrm{NH}_{2}$ at 1581.92, 1382.09 , and $600-800 \mathrm{~cm}^{-1}$ decreased with the decrease of UiO-66- $\mathrm{NH}_{2}$ contents. On the contrary, with the decrease of UiO-66- $\mathrm{NH}_{2}$ contents, the characteristic peaks of $\mathrm{Ag}_{2} \mathrm{CO}_{3}$ at 1374.62 and $803.06 \mathrm{~cm}^{-1}$ increased obviously [51].

The powder XRD patterns (Fig. 1b) of the as-synthesized UiO-66- $\mathrm{NH}_{2}$ are in consistent with the reported ones [46], indicating that UiO-66- $\mathrm{NH}_{2}$ was successfully prepared. All the diffraction peaks of pristine $\mathrm{Ag}_{2} \mathrm{CO}_{3}$ matched well with the standard pattern (JCPDS card No. 97-000-8011) (Fig. S3) of $\mathrm{Ag}_{2} \mathrm{CO}_{3}$ with monoclinic structure [50]. It is worth noting that the characteristic peaks of both UiO-66- $\mathrm{NH}_{2}$ and $\mathrm{Ag}_{2} \mathrm{CO}_{3}$ could be
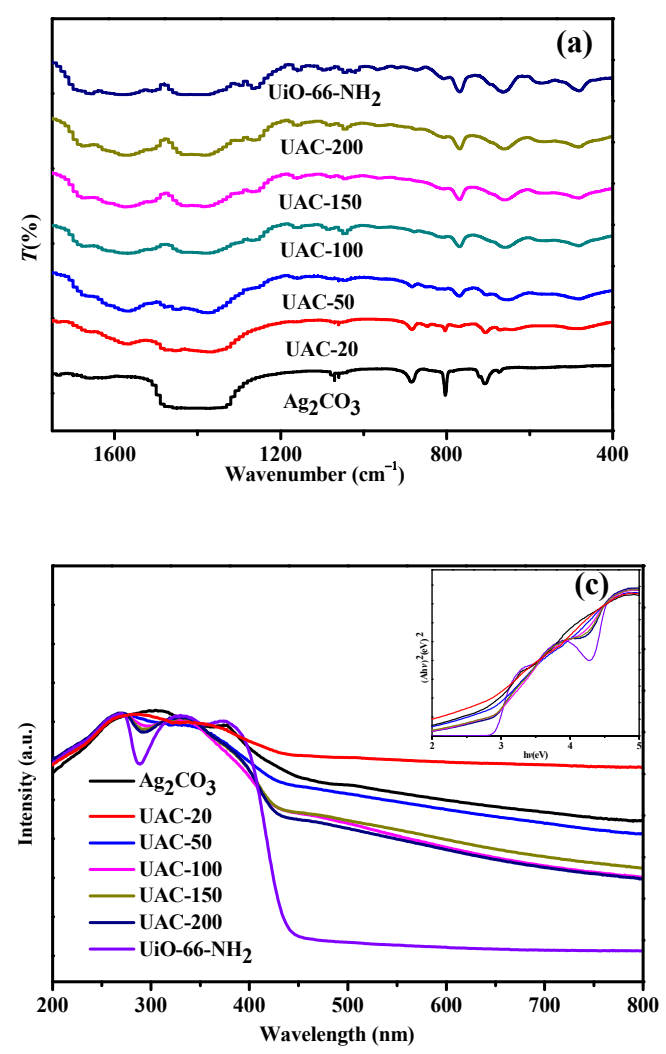
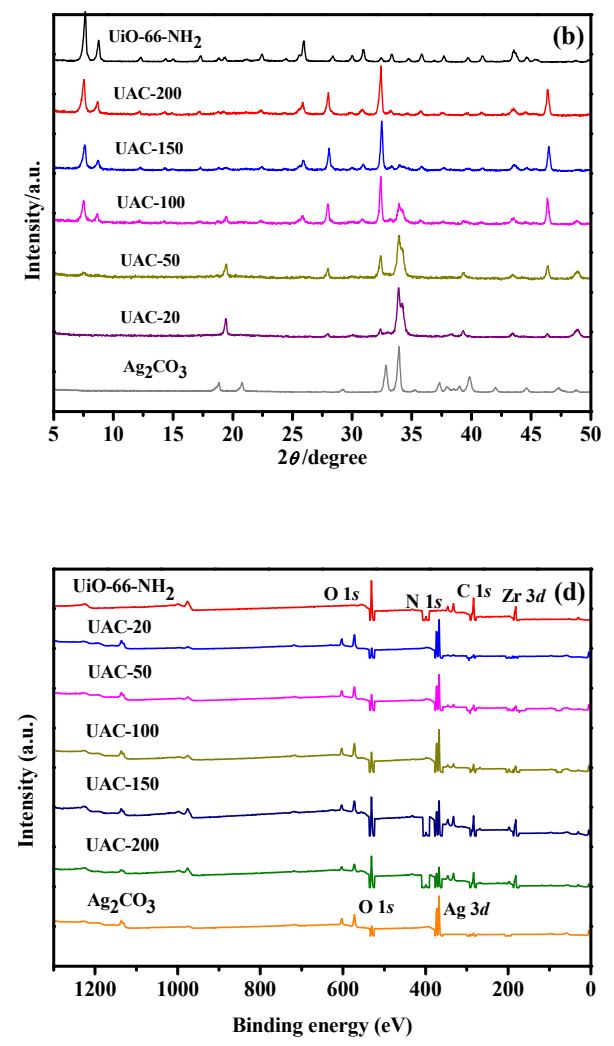

Fig. 1. (a) FTIR spectra, (b) PXRD patterns, (c) UV-vis DRS and $E_{\mathrm{g}}$ plot (inset), and (d) XPS spectra of $\mathrm{Ag}_{2} \mathrm{CO}_{3}, \mathrm{UiO}^{-66}-\mathrm{NH}_{2}$, and the UAC- $\mathrm{X}$ composites. 


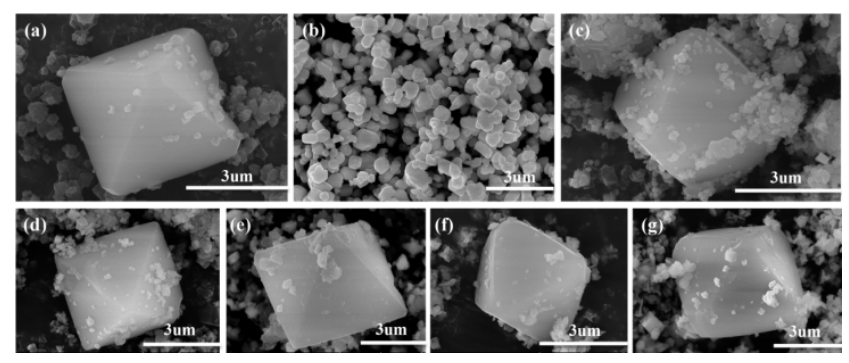

Fig. 2. SEM images of (a) Ui0-66- $\mathrm{NH}_{2}$, (b) $\mathrm{Ag}_{2} \mathrm{CO}_{3}$, (c) UAC-20, (d) UAC-50, (e) UAC-100, (f) UAC-150, and (g) UAC-200.

detected in UAC-100. The peaks of $\mathrm{Ag}_{2} \mathrm{CO}_{3}$ vanished gradually as the small $\mathrm{Ag}_{2} \mathrm{CO}_{3}$ content decreased in UAC-150 and UAC-200. Similarly, the characteristic peaks of UiO-66- $\mathrm{NH}_{2}$ could be detectable in both UAC-20 and UAC-50 [51].

The UV-vis diffuse reflectance spectra (UV-vis DRS) of $\mathrm{Ag}_{2} \mathrm{CO}_{3}$, UiO-66- $\mathrm{NH}_{2}$, and UAC- $X$ composites are displayed in Fig. 1c. The peak of pristine UiO-66- $\mathrm{NH}_{2}$ is a wide peak between 200 and $430 \mathrm{~nm}$, which is consistent with the peak previously reported $[39,40]$. The light absorption region of $U A C-X$ is almost the same as that of $\mathrm{Ag}_{2} \mathrm{CO}_{3}$, and their $E_{\mathrm{g}}$ values are in the range of 2.25-2.95 (inset in Fig. 1c), indicating that both UiO-66- $\mathrm{NH}_{2}$ and UAC- $X$ composites can be excited by visible light [40].

The successful fabrication of UAC- $X$ composites was further confirmed by XPS determination (Fig. 1d). The XPS spectrum revealed that the $\mathrm{Ag} 3 d$ in UAC- $X$ displayed a slight shift to higher binding energy compared to the pristine $\mathrm{Ag}_{2} \mathrm{CO}_{3}$, which may be due to the synergy between UiO-66- $\mathrm{NH}_{2}$ substrate and $\mathrm{Ag}_{2} \mathrm{CO}_{3}[50,51]$.

The SEM and TEM images could be used to specifically un- derstand the morphology of $\mathrm{Ag}_{2} \mathrm{CO}_{3}$, UiO-66- $\mathrm{NH}_{2}$, and UAC- $X$ composites. It was observed by SEM (Fig. 2a) that the individual UiO-66- $\mathrm{NH}_{2}$ particles were standard regular octahedrons of different sizes ranging from $200 \mathrm{~nm}$ to $3500 \mathrm{~nm}$, in which the UiO-66- $\mathrm{NH}_{2}$ with small particle size exhibited regular octahedrons shape (as shown in Fig. S4). $\mathrm{Ag}_{2} \mathrm{CO}_{3}$ presents irregular cubic structure [27] with particle size distribution between 100 and $400 \mathrm{~nm}$. Both SEM (Fig. 2) and TEM (Fig. S5) images illustrated that $\mathrm{Ag}_{2} \mathrm{CO}_{3}$ nanoparticles are adhered to the surface of UiO-66- $\mathrm{NH}_{2}$. The HRTEM image of UAC-100 (Fig. S6) reveals that the lattice spacing of $0.261 \mathrm{~nm}$ corresponds to the (130) facet of $\mathrm{Ag}_{2} \mathrm{CO}_{3}$, further indicating the intimate contact between UiO-66- $\mathrm{NH}_{2}$ and $\mathrm{Ag}_{2} \mathrm{CO}_{3}$ [51]. The content of octahedral UiO-66- $\mathrm{NH}_{2}$ in UAC- $X$ composites affected the adhesion state of $\mathrm{Ag}_{2} \mathrm{CO}_{3}$ on UiO-66- $\mathrm{NH}_{2}$. The element distribution results of UAC-100 are depicted in Fig. S7, in which the Ag, Zr, C, N, and $\mathrm{O}$ elements are evenly distributed over the composite, further indicating that $\mathrm{Ag}_{2} \mathrm{CO}_{3}$ is successfully loaded onto the UiO-66- $\mathrm{NH}_{2}$ material. In the XPS spectrum of UAC-100 (Fig. 3), the combination between $\mathrm{Ag}_{2} \mathrm{CO}_{3}$ and UiO-66- $\mathrm{NH}_{2}$ was affirmed by the shift of binding energies of $\mathrm{Zr}, \mathrm{Ag}, \mathrm{C}, \mathrm{N}$, and $\mathrm{O}$, which was deeply discussed in our previous reports $[50,51]$.

\subsection{Photocatalytic performance}

\subsubsection{Photocatalytic Cr(VI) reduction}

In order to explore the photocatalytic performance of $\mathrm{Ag}_{2} \mathrm{CO}_{3}$, UiO-66- $\mathrm{NH}_{2}$ and UAC- $X$ composites, the $\mathrm{Cr}(\mathrm{VI})$ reduction efficiency at $\mathrm{pH}=2$ was investigated. As shown in Fig. $4 \mathrm{a}$, $\mathrm{Cr}(\mathrm{VI})$ can not be reduced to $\mathrm{Cr}$ (III) without adding photocatalyst both in dark and under the irradiation of visible light. In the experiment, $\mathrm{Cr}(\mathrm{VI})$ was first adsorbed in the dark for $45 \mathrm{~min}$,
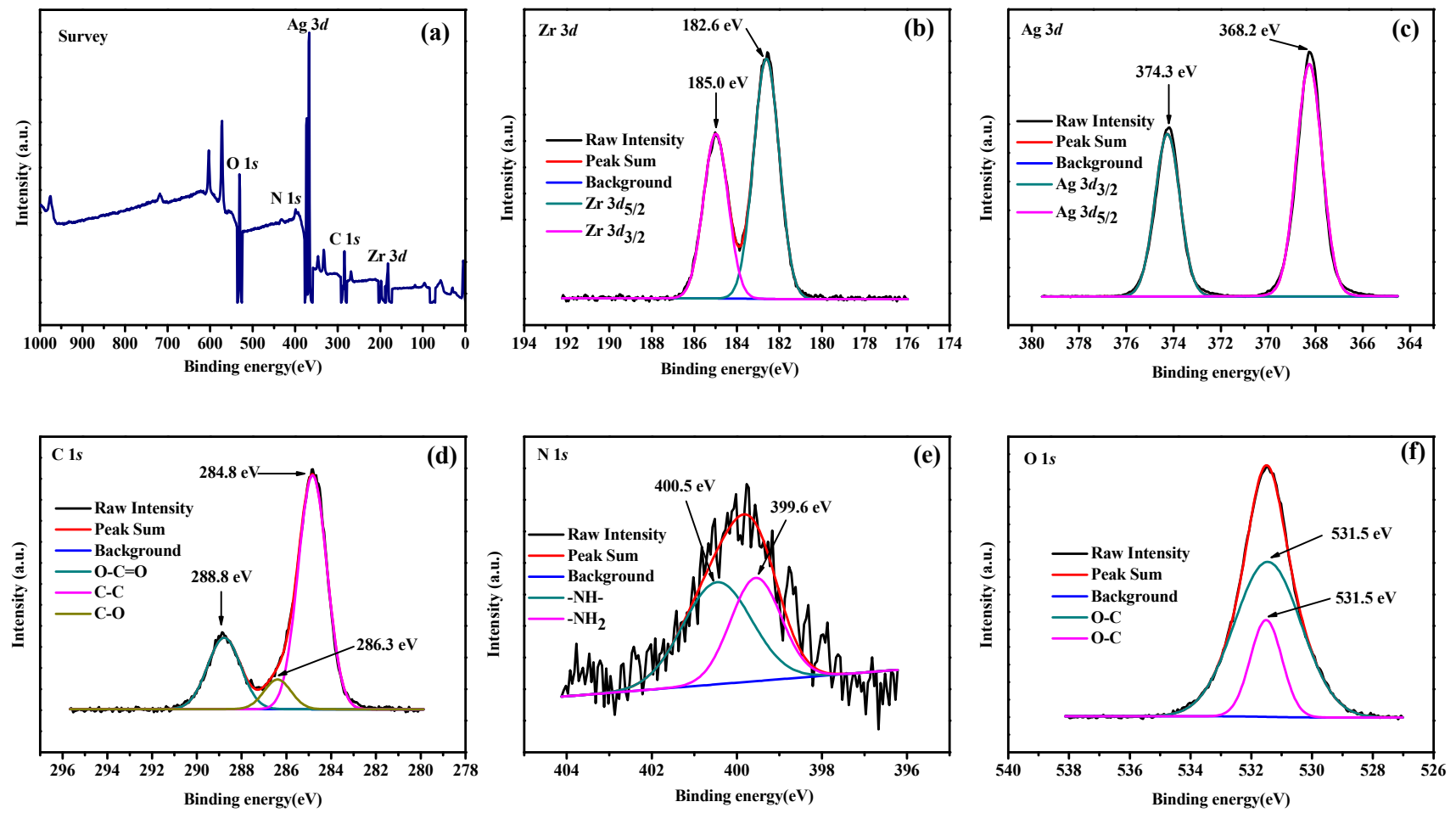

Fig. 3. (a) XPS survey, (b) Zr 3d, (c) Ag 3d, (d) C $1 s$, (e) N 1s, and (f) $01 s$ spectra of UAC-100 composite. 

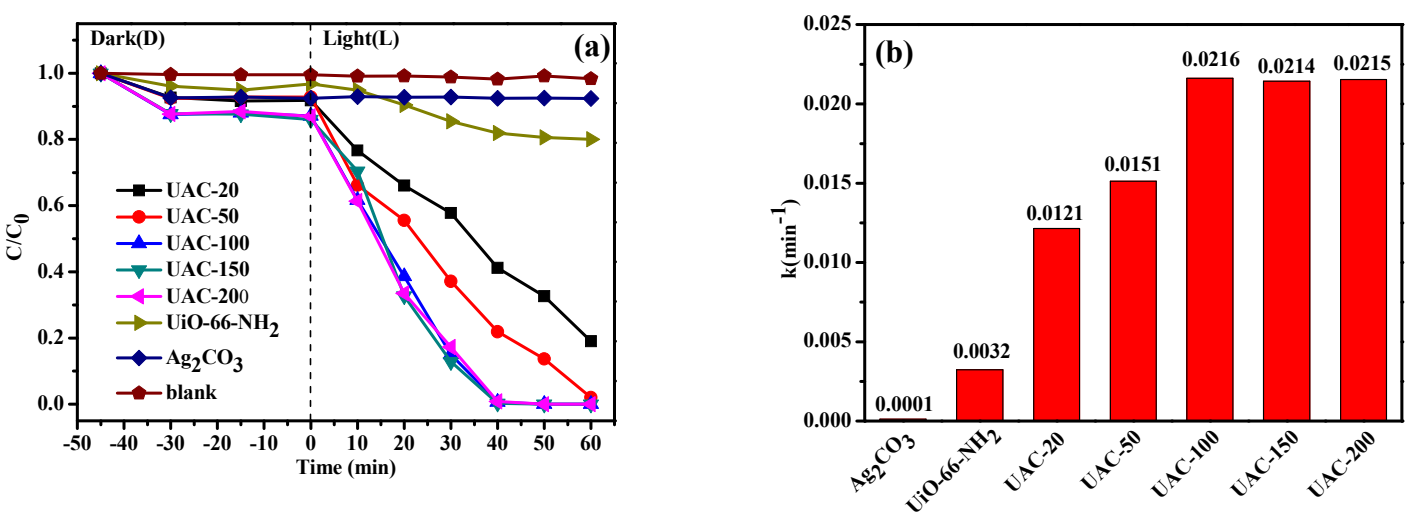

Fig. 4. (a) The adsorption and photocatalytic performance and (b) the photocatalytic reduction rates $\left(k\right.$ values) of $\mathrm{Ag}_{2} \mathrm{CO}_{3}$, UiO-66- $\mathrm{NH}_{2}$, and $\mathrm{UAC} \mathrm{X}$ composites toward $\mathrm{Cr}(\mathrm{VI})$ reduction. Conditions: $\mathrm{Cr}(\mathrm{VI})=10 \mathrm{mg} / \mathrm{L}$, volume $40 \mathrm{~mL}$, $\mathrm{pH}=2$, photocatalyst dosage $10 \mathrm{mg}$.

and the adsorptive removal efficiencies of $\mathrm{Ag}_{2} \mathrm{CO}_{3}, \mathrm{UiO}-66-\mathrm{NH}_{2}$, and UAC- $X$ composites toward $\mathrm{Cr}(\mathrm{VI})$ ranged from $3 \%$ to $14 \%$. As shown in Fig. 4a and Table 1, under the identical conditions, the photocatalytic performance of the UAC- $X$ composites for $\mathrm{Cr}(\mathrm{VI})$ reduction is better than those of pristine UiO-66- $\mathrm{NH}_{2}$ or $\mathrm{Ag}_{2} \mathrm{CO}_{3}$. UAC-100, UAC-150, and UAC-200 can achieve $100 \%$ $\mathrm{Cr}(\mathrm{VI})$ reduction within $50 \mathrm{~min}$, which are higher than the reduction efficiencies of UAC-20 (68\%), UAC-50 (86\%), UiO-66- $\mathrm{NH}_{2}$ (19\%), and $\mathrm{Ag}_{2} \mathrm{CO}_{3}$ (8\%). Specifically, the pseudo-first-order model of UAC- $X$ for $\mathrm{Cr}(\mathrm{VI})$ reduction further proves that UAC-100 achieved faster efficient reduction rate $(k$ value), as shown in Fig. 4b. Comparing with the UAC-20 and UAC-50, UAC-100 exhibited more outstanding photocatalytic performance toward $\mathrm{Cr}(\mathrm{VI})$ reduction under the identical conditions, which may be related to the larger specific surface area of UAC-100 than both UAC-20 and UAC-50 (Table S1). Both the positive zeta potential (Fig. S8c) and larger surface are facilitate the adsorption toward $\mathrm{Cr}_{2} \mathrm{O}_{7}^{2-}$ for further photocatalysis $[29,37]$. As well, the appropriate introduction of $\mathrm{Ag}_{2} \mathrm{CO}_{3}$ into UiO-66- $\mathrm{NH}_{2}$ will improve the charge transfer over the composite interfaces under visible light irradiation [54]. However, excessive UiO-66- $\mathrm{NH}_{2}$ in the UAC- $X$ may suppress the valid heterogeneous interfaces, which is not conducive to the transfer of charge carriers [55]. In view of economic and cost savings, UAC-100 can achieve the desired effect under the same conditions using less UiO-66- $\mathrm{NH}_{2}$ compared to UAC-150 and UAC-200. Therefore, the UAC-100 was selected to conduct follow-up experiments for deep understand toward its perfor-

Table 1

Photocatalytic $\mathrm{Cr}(\mathrm{VI})$ reduction efficiencies (\%) of different photocatalysts.

\begin{tabular}{lccc}
\hline \multirow{2}{*}{ Catalyst } & \multicolumn{3}{c}{ Efficiency (\%) } \\
\cline { 2 - 4 } & $40 \mathrm{~min}$ & $50 \mathrm{~min}$ & $60 \mathrm{~min}$ \\
\hline $\mathrm{UAC}-20$ & 59 & 68 & 81 \\
$\mathrm{UAC}-50$ & 78 & 86 & 98 \\
$\mathrm{UAC}-100$ & 99 & 100 & 100 \\
$\mathrm{UAC}-150$ & 99 & 100 & 100 \\
$\mathrm{UAC}-200$ & 99 & 100 & 100 \\
$\mathrm{UiO}^{-66}-\mathrm{NH}_{2}$ & 18 & 19 & 20 \\
$\mathrm{Ag}_{2} \mathrm{CO}_{3}$ & 8 & 8 & 8 \\
\hline
\end{tabular}

mance.

\subsubsection{Effect of initial $p H$ value on Cr(VI) reduction}

The initial $\mathrm{pH}$ value of $\mathrm{Cr}(\mathrm{VI})$ has a great influence on its reduction effect [56]. In this study, the effects of different $\mathrm{pH}$ values $(\mathrm{pH}=2,3,4,6,8)$ on the $\mathrm{Cr}(\mathrm{VI})$ reduction were investigated using UAC-100 as photocatalyst. As illustrated in Fig. 5a, the lower $\mathrm{pH}$ resulted in a better photocatalytic efficiency and rate. Especially, the highest photocatalytic $\mathrm{Cr}(\mathrm{VI})$ reduction efficiency (99.0\% within $40 \mathrm{~min}$ and $100.0 \%$ within $50 \mathrm{~min}$ ) was accomplished at $\mathrm{pH}=2.0$. It is well known that hexavalent chromium exists in the form of $\mathrm{Cr}_{2} \mathrm{O}_{7}{ }^{2-}$ at low $\mathrm{pH}$ [37]. At this lower $\mathrm{pH}$, the higher degree of protonation on the catalyst surface facilitates the adsorptive interactions with $\mathrm{Cr}_{2} \mathrm{O}_{7}{ }^{2-}$ ions, and the abundant $\mathrm{H}^{+}$also promotes the transformation from $\mathrm{Cr}(\mathrm{VI})$ to Cr(III), as listed in Eq. (1) [56]. Under alkaline conditions, the composite photocatalysts displayed negative zeta potentials (as illustrated in Fig. S8), which would decline the adsorptive interactions toward anionic $\mathrm{CrO}_{4}{ }^{2-}$. As well, the $\mathrm{Cr}(\mathrm{VI})$ reduction reaction under alkaline surroundings follows Eq. (2) [17]. However, the formed $\mathrm{Cr}(\mathrm{OH})_{3}$ can cover the active sites over the catalyst surface, resulting into declined photocatalytic efficiency.

$$
\begin{aligned}
& \mathrm{Cr}_{2} \mathrm{O}_{7}^{2-}+14 \mathrm{H}^{+}+6 \mathrm{e}^{-} \rightarrow 2 \mathrm{Cr}^{3+}+7 \mathrm{H}_{2} \mathrm{O} \\
& \mathrm{CrO}_{4}^{2-}+4 \mathrm{H}_{2} \mathrm{O}+3 \mathrm{e}^{-} \rightarrow \mathrm{Cr}(\mathrm{OH})_{3} \downarrow+5 \mathrm{OH}^{-}
\end{aligned}
$$

\subsubsection{Effects of foreign ions on $\mathrm{Cr}(\mathrm{VI})$ reduction}

In order to explore the influences of foreign ions on the photocatalytic $\mathrm{Cr}(\mathrm{VI})$ reduction activity, UAC-100 catalyst was used to treat a $\mathrm{Cr}(\mathrm{VI})$ solution $(\mathrm{pH}=2)$ prepared with real lake water collected from the Ming Lake and tap water of Daxing campus, BUCEA (the quality parameters of lake water and tap water are shown in Table S2). As shown in Fig. 5b, it was found that the $\mathrm{Cr}(\mathrm{VI})$ reduction efficiency declined from $100 \%$ to $46 \%$ in $60 \mathrm{~min}$, indicating that the $\mathrm{Cr}(\mathrm{VI})$ reduction over UAC-100 was inhibited by the inorganic ions in tap water [44]. It is worth noting that the $\operatorname{Cr}(\mathrm{VI})$ reduction efficiency in lake water was higher $(76 \%, 60 \mathrm{~min})$ than that in tap water because the organic matters in the lake water could consume the holes to facilitate the separation of photo-induced electrons and holes 

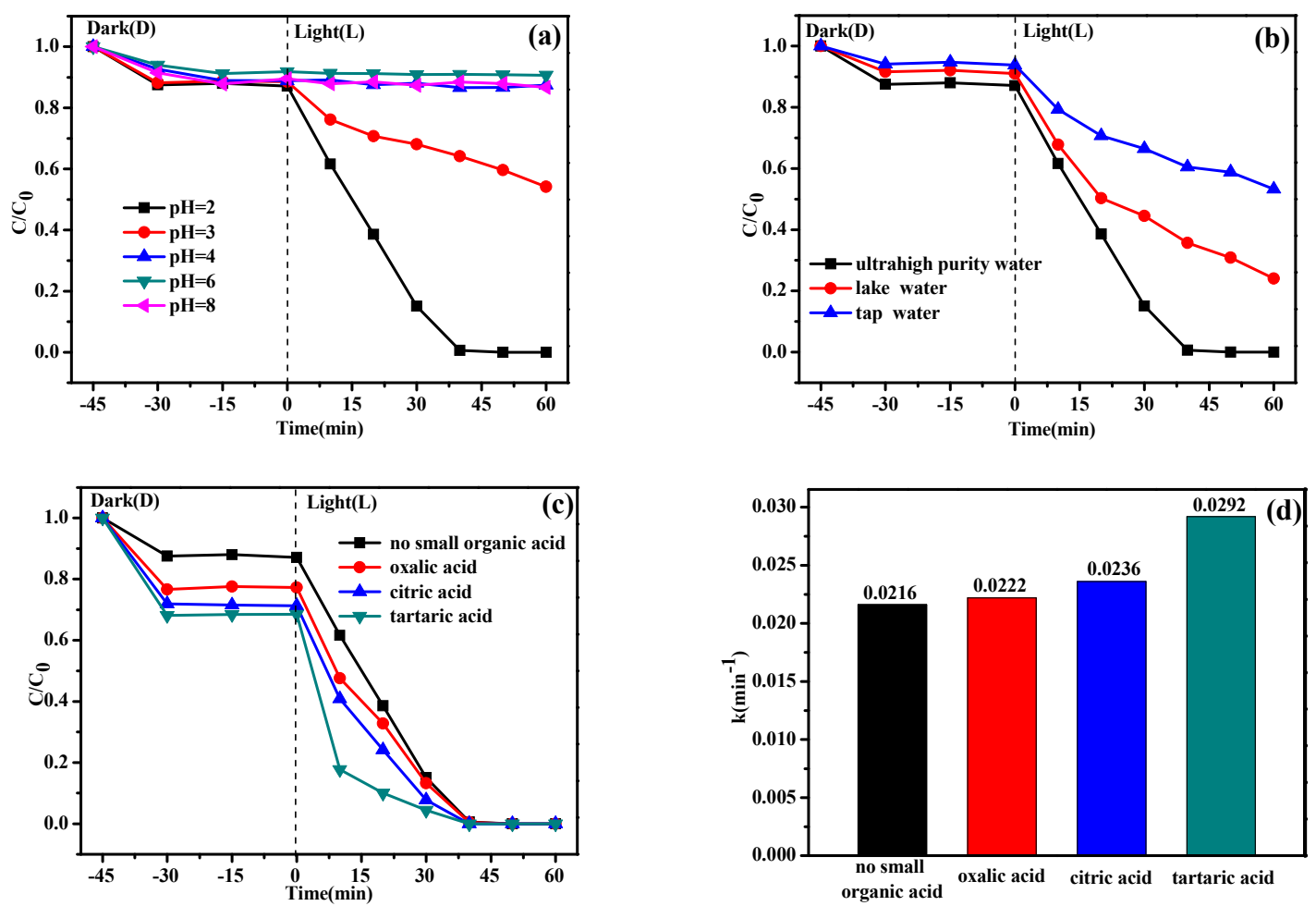

Fig. 5. (a) Photocatalytic $\mathrm{Cr}(\mathrm{VI})$ reduction efficiencies with UAC-100 as photocatalyst at different pH values; (b) Effect of $\mathrm{Cr}(\mathrm{VI}) \mathrm{solution}$ prepared from tap water and lake water on reduction of $\mathrm{Cr}(\mathrm{VI})$; (c) Effect of different small organic acids on the $\mathrm{Cr}(\mathrm{VI})$ reduction; (d) Photocatalytic $\mathrm{Cr}(\mathrm{VI})$ reduction rates ( $k$ values) in the presence of different small organic compounds. Conditions: UAC-100 $=10 \mathrm{mg}, \mathrm{Cr}(\mathrm{VI})=10 \mathrm{mg} / \mathrm{L}, 40 \mathrm{~mL}$, $\mathrm{pH}=2.0$, small organic acid dosage $=0.1 \mathrm{mmol} / \mathrm{L}$.

[57]. It can be concluded that the organic matters in the reaction system can enhance the photocatalytic $\mathrm{Cr}(\mathrm{VI})$ reduction performance.

\subsubsection{Effects of small organic acids on $\mathrm{Cr}$ (VI) reduction}

Photo-induced electron-hole pairs can be produced upon visible light irradiation. The consumption of holes $\left(\mathrm{h}^{+}\right)$will accelerate the charge separation of photo-induced electron-hole pairs, resulting in excellent $\mathrm{Cr}(\mathrm{VI})$ reduction efficiency. In order to test the effect of small organic acids as hole scavengers on the $\mathrm{Cr}(\mathrm{VI})$ reduction efficiency, some organic compounds such as citric acid, tartaric acid, and oxalic acid were selected as hole scavengers at $\mathrm{pH}=2.0$. As shown in Fig. $5 \mathrm{c}$ and $5 \mathrm{~d}$, the participation of these small organic acids can improve the photocatalytic $\mathrm{Cr}(\mathrm{VI})$ reduction activity, because the organic matters consume the holes generated over the UAC-100 photocatalyst upon light irradiation. It is worth noting that the presence of small organic compounds can improve the photocatalytic reaction rate of $\mathrm{Cr}(\mathrm{VI})$ reduction, which may be related to the number of $\alpha$-hydroxyl carboxylate functional groups (zero, one, and two $\alpha$-hydroxyl groups in oxalic acid, citric acid, and tartaric acid, respectively) [12,39].

\subsubsection{Photocatalytic degradation activities toward different organic dyes}

Different organic dyes like rhodamine $\mathrm{B}(\mathrm{RhB})$, methyl orange (MO), congo red (CR), and methylene blue (MB) were selected to investigate the degradation performance of UAC-100. UAC-100 displayed negative zeta potential when $\mathrm{pH}$ was higher than 3.3 (pHpzc) (Fig. S8), which favored the adsorption toward cationic organic dyes. During the adsorption process in dark, UAC-100 displayed different adsorption performance toward cationic RhB and MB along with anionic MO and CR. It can be found that UAC-100 exhibits the best adsorption ability toward MB due to electrostatic interaction. Howev$\mathrm{er}$, the size of $\mathrm{RhB}(1.56 \mathrm{~nm} \times 1.35 \mathrm{~nm} \times 0.42 \mathrm{~nm})$ is slightly larger than MB $(1.38 \mathrm{~nm} \times 0.64 \mathrm{~nm} \times 0.21 \mathrm{~nm})$, and the pore size of UAC-100 is ca. $0.6 \mathrm{~nm}$ (Fig. S9), which leads to the poorer adsorption performance toward RhB than that toward MB. With the aid of weak interaction between $\mathrm{Ag}^{+}$in UAC-100 and the $-\mathrm{NH}_{2}$ group $[50,51,58]$, UAC- 100 displays noticeable adsorption toward CR with the adsorption efficiency of $28 \%$. And, the electrostatic repulsion between UAC-100 and MO leads to nearly no adsorptive interactions. Upon the light irradiation, 96\% MB and 81\% CR can be decomposed within $60 \mathrm{~min}$, while $90 \% \mathrm{MO}$ and $85 \% \mathrm{RhB}$ can be degraded up to $90 \mathrm{~min}$. It can be concluded that UAC-100 can achieve the photocatalytic degradation toward organic pollutants like stable organic dyes.

\subsubsection{Identification of active species}

In order to further understand the intrinsic reactions, some measures were taken to explore the active species that play a role in the process of photocatalytic. Specifically, EDTA-2Na (0.2 mmol/L), benzoquinone (BQ, $0.2 \mathrm{mmol} / \mathrm{L})$, and isopropyl 


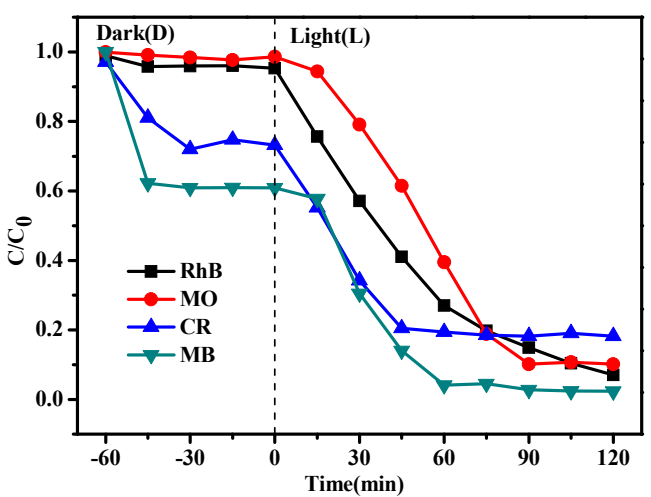

Fig. 6. The photocatalytic degradation performance of UAC-100 toward different organic dyes (RhB, MO, CR, MB). Reaction conditions: $10 \mathrm{mg}$ UAC- $100,40 \mathrm{~mL}$ of RhB (10 mg/L) or MO (10 mg/L) or CR (50 mg/L) or $\mathrm{MB}(10 \mathrm{mg} / \mathrm{L})$.

alcohol (IPA, $0.6 \mathrm{mmol} / \mathrm{L}$ ) were added to the solution to capture $\mathrm{h}^{+}, \bullet \mathrm{O}_{2}$, and $\bullet \mathrm{HO}$, respectively. It has been pointed out that - $\mathrm{HO}$ and $\bullet \mathrm{O}_{2^{-}}$are important photoactive substances that can degrade pollutants $[16,27,31,44,59]$. As shown in Fig. 7 a, the degradation of MB by UAC-100 was significantly inhibited after the addition of different sacrificial agents, indicating that all the $\mathrm{h}^{+}, \bullet \mathrm{HO}$, and $\bullet \mathrm{O}_{2}-$ can achieve the oxidative degradation toward the organic dyes under visible light. The electron spin resonance (ESR) determination can also prove the existence of $\bullet \mathrm{O}_{2}$ and $\bullet \mathrm{HO}$, as shown in Fig. $7 \mathrm{~b}$ and $7 \mathrm{c}$.

\subsubsection{Photocatalytic performance toward $\mathrm{Cr}(\mathrm{VI})$ and $M B$ in} their matrix

It is well known that heavy metals like Cr(VI) often existed with various organic pollutants in industrial wastewater. In this experiment, the photocatalytic activity of UAC-100 for simultaneous $\mathrm{Cr}(\mathrm{VI})$ reduction and organic dye degradation at $\mathrm{pH}=2$ was investigated. As shown in Fig. 8, in the mono-system of $\mathrm{Cr}(\mathrm{VI})$ and MB, UAC-100 could remove $100 \% \mathrm{Cr}(\mathrm{VI})$ and $96 \%$ MB after 60 min illumination, respectively. However, in the $\mathrm{Cr}(\mathrm{VI})$ and MB matrix, only $79 \% \mathrm{Cr}(\mathrm{VI})$ and $78 \%$ MB were removed under visible light for $60 \mathrm{~min}$. The removal efficiency of both $\mathrm{Cr}(\mathrm{VI})$ and MB over UAC-100 in the mixed system became slower than that of the mono-component, possibly due to the

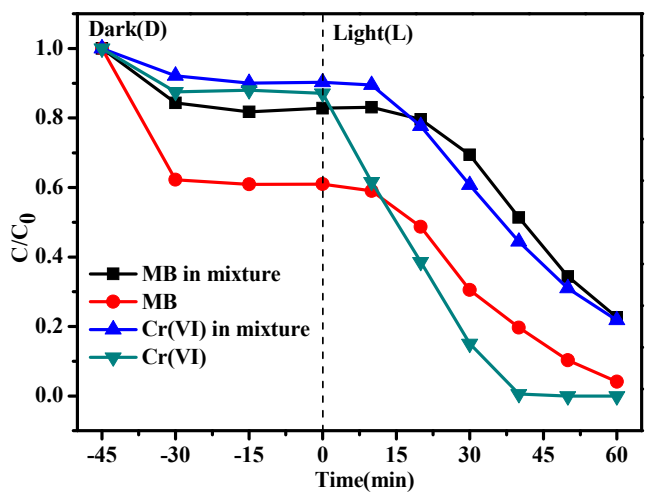

Fig. 8. Photocatalytic $\mathrm{Cr}(\mathrm{VI})$ reduction and $\mathrm{MB}$ degradation efficiencies in their single systems and in their matrix with UAC-100 as photocatalyst. Reaction conditions: $10 \mathrm{mg}$ UAC-100, $40 \mathrm{~mL}$ of $\mathrm{Cr}(\mathrm{VI})(10 \mathrm{mg} / \mathrm{L})$ and $\mathrm{MB}(10 \mathrm{mg} / \mathrm{L}), \mathrm{pH}=2.0$.

competition of $\bullet \mathrm{O}_{2}$ - between $\mathrm{Cr}(\mathrm{VI})$ and $\mathrm{MB}$ (detailed discussion can be found in Section 3.2.5).

\subsubsection{Reusability and stability of UAC-100}

It is important to explore the reusability and stability of the UAC- $X$ composites for practical application, which was performed by accomplishing repeated cycles under determinate reaction conditions. As illustrated in Fig. 9a, UAC-100 shows the superior photocatalytic $\mathrm{Cr}(\mathrm{VI})$ reduction activity of more than 99\% after four cycles. The PXRD patterns (Fig. 9b) of the recovered UAC-100 after four cycles matched well with the original ones, implying that UAC-100 has excellent reusability and stability. In addition, there is no obvious change in the octahedron shape of UiO-66- $\mathrm{NH}_{2}$ after four runs (Fig. S10), indicating that the composite material can be reused without obvious erosion and deterioration. The XPS spectrum of UAC-100 after the photocatalytic reaction further demonstrates the integrity of UAC-100 (as shown in Fig. S11), which has only a small amount of $\mathrm{Cr}(\mathrm{III})$ formed by $\mathrm{Cr}(\mathrm{VI})$ reduction (the binding energy of $573.3 \mathrm{eV}$ corresponds to $\mathrm{Cr} 2 p_{3 / 2}$ orbital of $\mathrm{Cr}(\mathrm{III})$ ) [60].

It should be noted that $99 \% \mathrm{Cr}(\mathrm{VI})$ reduction can be achieved after four cycles of visible light irradiation for $50 \mathrm{~min}$ over UAC-100 without adding any hole scavenger to promote the reaction. Compared to some typical metal-organic frame-
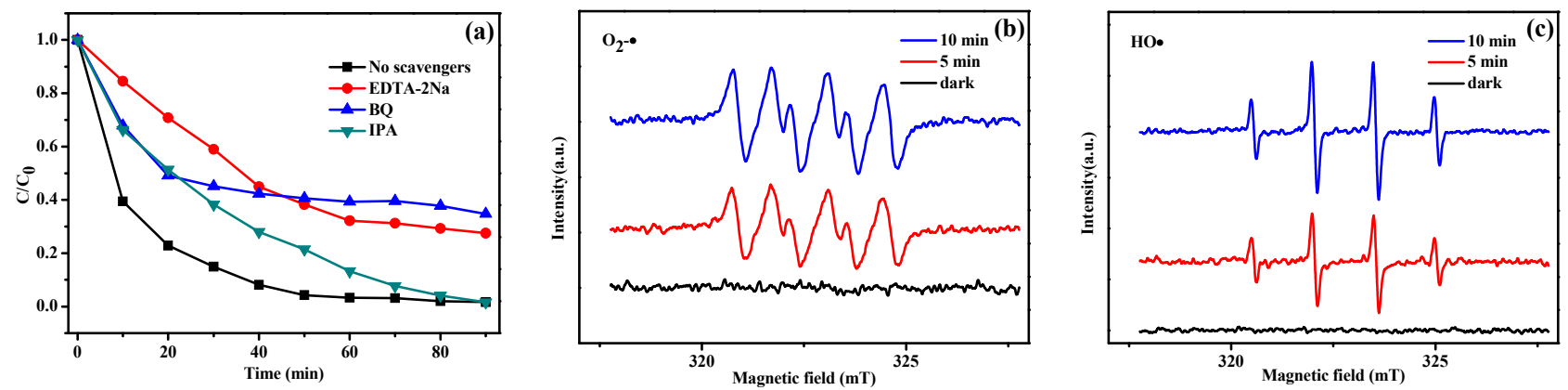

Fig. 7. (a) The effects of different scavengers on the degradation of $M B$ in the presence of UAC-100 under visible light irradiation. Conditions: MB = 10 $\mathrm{mg} / \mathrm{L}, 40 \mathrm{~mL}, \mathrm{UAC}-100=10 \mathrm{mg}$. ESR spectra of radical adducts trapped by DMPO- $\bullet \mathrm{O}_{2}^{-}$(b) and DMPO- $\bullet \mathrm{HO}$ (c) over UAC-100 under visible light irradiation. 

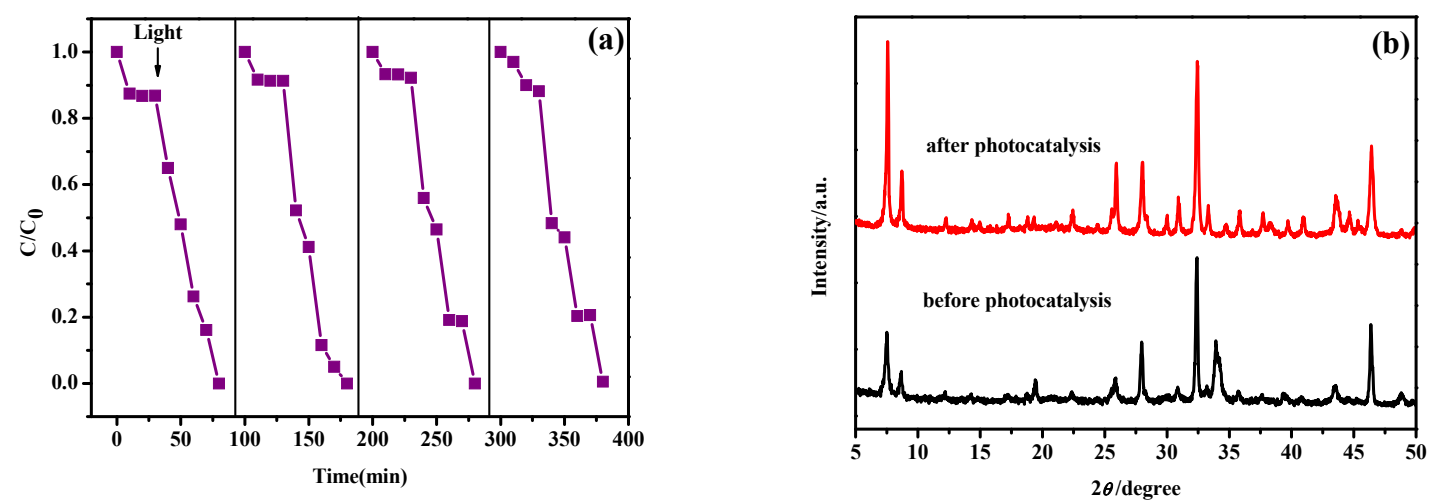

Fig. 9. (a) The reusability of UAC-100 under visible light conditions (photocatalytic reduction of $\mathrm{Cr}(\mathrm{VI})$ ) and dark conditions (adsorption of $\mathrm{Cr}_{2} \mathrm{O}_{7}{ }^{2-}$ ); (b) Comparison of PXRD before and after four cycles of photocatalytic $\mathrm{Cr}(\mathrm{VI})$ reduction solution by UAC-100 composite.

works or their composites, UAC-100 exhibits an excellent ability to reduce $\mathrm{Cr}(\mathrm{VI})$ after 50 min irradiation under 5.00 W LED, as illustrated in Table 2. It is found that UAC-100 displayed superior photocatalytic $\mathrm{Cr}(\mathrm{VI})$ performance among the reported photocatalysts in Table 2, considering the photocatalyst dosage, initial $\mathrm{Cr}(\mathrm{VI})$ concentration, solution volume, cycle times, and light source.

\subsubsection{Photocatalytic reaction mechanism}

The photoluminescence technique (PL) was used to evaluate the separation efficiency of carrier charges in catalytic process of the composites $[41,64,65]$. Generally, the higher fluorescence emission intensity implies the faster recombination of photo-induced electrons and holes, resulting in a decrease of the photocatalytic performance. UiO-66- $\mathrm{NH}_{2}, \mathrm{Ag}_{2} \mathrm{CO}_{3}$, and UAC-100 are excited to produce the excitation peak centered at $350 \mathrm{~nm}$. However, UAC-100 displayed a slight blue-shift relative to UiO-66- $\mathrm{NH}_{2}$ and $\mathrm{Ag}_{2} \mathrm{CO}_{3}$, in which the emission peaks of UiO-66- $\mathrm{NH}_{2}, \mathrm{Ag}_{2} \mathrm{CO}_{3}$, and UAC-100 are centered at 542, 540, and $540 \mathrm{~nm}$, respectively. It can be seen from Fig. 10a that the fluorescence intensity of UAC-100 is significantly weaker than that of UiO-66- $\mathrm{NH}_{2}$ and $\mathrm{Ag}_{2} \mathrm{CO}_{3}$, indicating that photo-induced electrons and holes over UAC-100 are effectively separated. This can also be confirmed by the transient photocurrent response value $[64,65]$. The photo-electrode prepared from UAC-100 can generate reversible and stable photocurrent under visible light illumination, and the photocurrent intensity of
UAC-100 is obviously higher than that of UiO-66- $\mathrm{NH}_{2}$ and $\mathrm{Ag}_{2} \mathrm{CO}_{3}$ (Fig. S12). The transient photocurrent responses further prove that the separation efficiency of photo-induced electron and hole pairs over the composites is improved significantly.

Electrochemical impedance spectroscopy (EIS) of UiO-66- $\mathrm{NH}_{2}, \mathrm{Ag}_{2} \mathrm{CO}_{3}$, and UAC-100 was performed for analysis of charge transfer and recombination, in which the diameter of the arc on an EIS Nyquist diagram is equal to the charge transfer resistance occurred at the semiconductor-electrolyte interface [66]. The smaller Nyquist radius implied the smaller corresponding charge transfer resistance. As depicted in Fig. 10b, the arc radius of the UAC-100 composite is much smaller than that of UiO-66- $\mathrm{NH}_{2}$ and $\mathrm{Ag}_{2} \mathrm{CO}_{3}$, indicating that the photo-induced holes and electrons over the UAC-100 are effectively separated to accomplish the higher photocatalytic activity.

The Mott-Schottky curves of $\mathrm{Ag}_{2} \mathrm{CO}_{3}$ and UiO-66- $\mathrm{NH}_{2}$ (Fig. $10 \mathrm{c}$ and $10 \mathrm{~d}$ ) illustrate negative and positive correction between $C^{2}$ value and potential value, implying that $\mathrm{Ag}_{2} \mathrm{CO}_{3}$ and UiO-66- $\mathrm{NH}_{2}$ displayed the typical behavior of p-type semiconductor and n-type semiconductor, respectively [67]. Compared with the pristine $\mathrm{Ag}_{2} \mathrm{CO}_{3}$ and UiO-66- $\mathrm{NH}_{2}$, the enhanced photocatalytic activity of UAC- $X$ composites may be assigned to the p-n junction formed between the n-type UiO-66- $\mathrm{NH}_{2}$ and the p-type $\mathrm{Ag}_{2} \mathrm{CO}_{3}$ semiconductor. It can be roughly inferred from the Mott-Schottky spectrogram that the flat band potentials ( $E_{\mathrm{FB}}$ ) of UiO-66- $\mathrm{NH}_{2}$ and $\mathrm{Ag}_{2} \mathrm{CO}_{3}$ are $c a-1.29$ and $0.51 \mathrm{eV}$ vs

Table 2

Performance of some typical metal-organic frameworks (or their composites) as photocatalysts for the reduction of Cr(VI) under visible light irradiation.

\begin{tabular}{|c|c|c|c|c|c|c|}
\hline $\begin{array}{l}\text { Photocatalyst/ } \\
\text { Amount (mg) }\end{array}$ & $\begin{array}{c}\mathrm{Cr}(\mathrm{VI}) \text { concentration } \\
(\mathrm{mg} / \mathrm{L}) / \text { Solution volume }(\mathrm{mL}) / \mathrm{pH}\end{array}$ & $\begin{array}{l}\text { Time } \\
\text { (min) }\end{array}$ & $\begin{array}{l}\text { 1st cycle reduction } \\
\text { efficiency }(\%)\end{array}$ & $\begin{array}{c}\text { Times/Last cycle } \\
\text { reduction efficiency } \\
(\%)\end{array}$ & Light source & Ref. \\
\hline MIL-101(Fe)/20 & $8 / 40 / 2.0$ & 60 & 100 & NA & 300 W Xe Lamp & [37] \\
\hline $\mathrm{NH}_{2}-\mathrm{MIL}-88 \mathrm{~B} / 20$ & $8 / 40 / 2.0$ & 50 & 100 & $4 / 100$ & $300 \mathrm{~W}$ Xe Lamp & [37] \\
\hline $\mathrm{UiO}-66-\mathrm{NH}_{2} / 20$ & $10 / 40 / 2.0$ & 80 & 97 & $3 / 97$ & 300 W Xe Lamp & {$[40,61]$} \\
\hline BUC-21/g- $\mathrm{C}_{3} \mathrm{~N}_{4} / 50$ & $10 / 200 / 2.0$ & 120 & ca. 97 & 5/ca. 89 & 500 W Xe Lamp & [39] \\
\hline Pd@UiO-66(NH 2$) / 20$ & $10 / 40 / 2.0$ & 90 & 100 & 3/ca. 98 & 300 W Xe Lamp & {$[62]$} \\
\hline RGO-UiO-66 $\left(\mathrm{NH}_{2}\right) / 20$ & $10 / 40 / 2.0$ & 100 & 100 & 3/са. 100 & 300 W Xe Lamp & [63] \\
\hline $\mathrm{UiO}-66-\mathrm{NH}_{2} / \mathrm{Ag}_{2} \mathrm{CO}_{3} / 10$ & $10 / 40 / 2.0$ & 50 & 100 & $4 / 99$ & $5.00 \mathrm{~W}$ LED & this work \\
\hline
\end{tabular}

Notes: BUC-21/g- $\mathrm{C}_{3} \mathrm{~N}_{4}$ reduced $\mathrm{Cr}(\mathrm{VI})$ under simulated sunlight. 

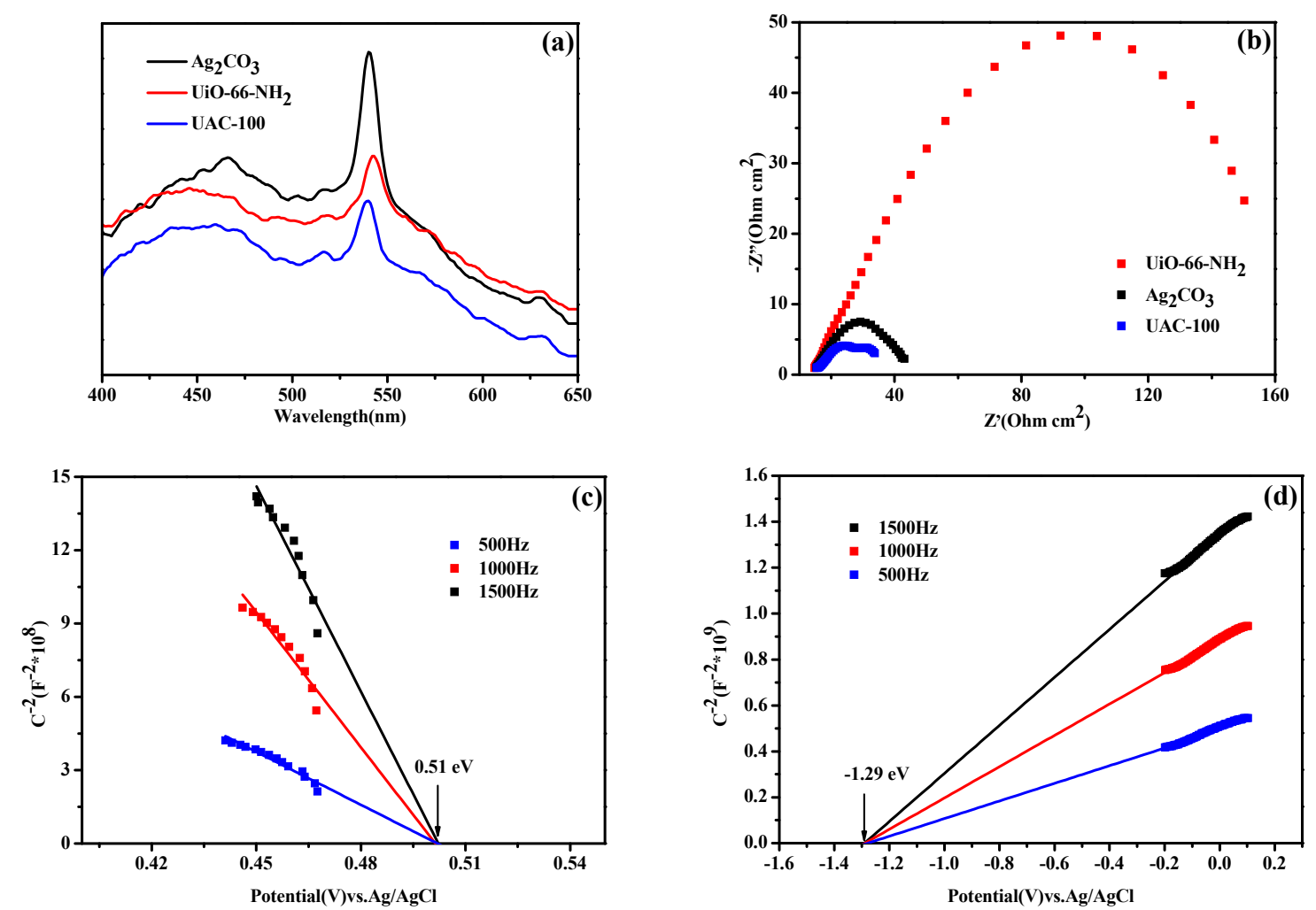

Fig. 10. (a) Photoluminescence spectra (PL) and (b) electrochemical impedance spectra (EIS); The Mott-Schottky curves of (c) Ag $\mathrm{CO}_{3}$ and (d) $\mathrm{UiO}-66-\mathrm{NH}_{2}$ at various frequencies.

$\mathrm{Ag} / \mathrm{AgCl}$ electrode, respectively. According to the band gap value $\left(E_{\mathrm{g}}\left(\mathrm{UiO}-66-\mathrm{NH}_{2}\right)=2.92 \mathrm{eV}, E_{\mathrm{g}}\left(\mathrm{Ag}_{2} \mathrm{CO}_{3}\right)=2.64 \mathrm{eV}\right)$ and $E_{\mathrm{FB}}$ in Mott-Schottky, the maximum occupied molecular orbital (HOMO) of UiO-66- $\mathrm{NH}_{2}$ and $\mathrm{VB}$ of $\mathrm{Ag}_{2} \mathrm{CO}_{3}$ were $1.83 \mathrm{eV}$ and $3.35 \mathrm{eV}$ vs NHE at $\mathrm{pH}=7.0$, respectively.

Based on the properties and experimental studies of the UAC-100 composite, UiO-66- $\mathrm{NH}_{2}$, and $\mathrm{Ag}_{2} \mathrm{CO}_{3}$, the possible direct Z-scheme photocatalytic mechanism of organic dyes and $\mathrm{Cr}(\mathrm{VI})$ reduction under the irradiation of visible light was proposed (Scheme 2) [68-72]. Under the visible light irradiation, the electrons in the highest occupied molecular orbital (HOMO) of UiO-66- $\mathrm{NH}_{2}$ will be excited to the lowest occupied molecular

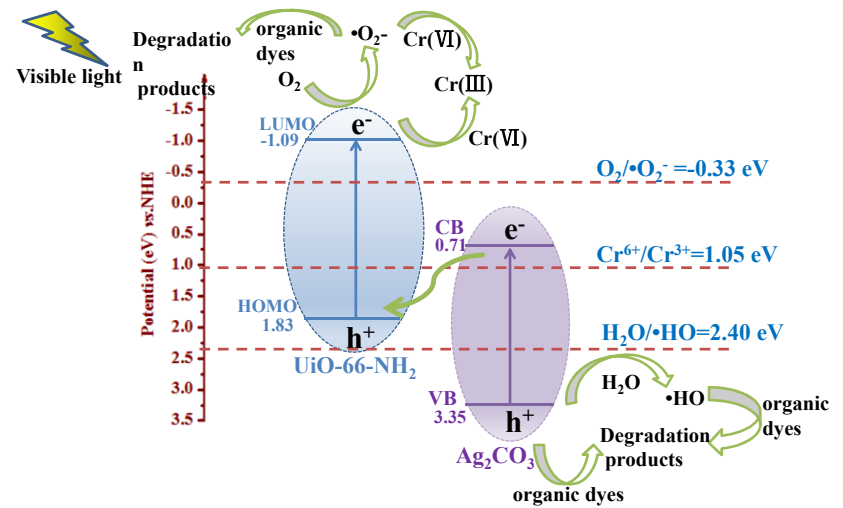

Scheme 2. The proposed Z-scheme mechanism for the photocatalytic $\mathrm{Cr}(\mathrm{VI})$ reduction and organic pollutant degradation over UAC-100 under visible light. orbital (LUMO), and similarly, the electrons in the VB position of $\mathrm{Ag}_{2} \mathrm{CO}_{3}$ will be excited to the $\mathrm{CB}$ position. Considering that the formation of UiO-66- $\mathrm{NH}_{2} / \mathrm{Ag}_{2} \mathrm{CO}_{3}$ (UAC-100), the photo-induced electrons can be transferred from the $\mathrm{CB}$ of $\mathrm{Ag}_{2} \mathrm{CO}_{3}$ to consume the $\mathrm{h}^{+}$formed over HOMO of UiO- $66-\mathrm{NH}_{2}$, which effectively shorten the electron transfer distance and facilitate the separation of electron-hole formed on the individual UiO-66- $\mathrm{NH}_{2}$ and $\mathrm{Ag}_{2} \mathrm{CO}_{3}$. The $\bullet \mathrm{O}_{2}$ - is a key active substance that exhibits direct oxidative degradation of organic dyes, which can be generated as the LUMO value of UiO- $66-\mathrm{NH}_{2}$ is $-1.29 \mathrm{eV}$ vs NHE, much more negative than the standard redox potential $E\left(\mathrm{O}_{2} / \bullet \mathrm{O}_{2}\right)(-0.33 \mathrm{eV}$ vs $\mathrm{NHE})[64]$. At the same time, $\mathrm{O}_{2}{ }^{-} \cdot$ will also participate in the photocatalytic $\mathrm{Cr}(\mathrm{VI})$ reduction via Eqs. (3) and (4) [73,74], which can be demonstrated by the inhibition of $\mathrm{Cr}(\mathrm{VI})$ reduction in nitrogen atmosphere compared to normal indoor environments under the same conditions, as shown in Fig. S13. It is worth noting that the electrons generated on the LUMO of UiO-66- $\mathrm{NH}_{2}$ will also directly participate in the $\mathrm{Cr}(\mathrm{VI})$ reduction because of the strong ability of $\mathrm{Cr}(\mathrm{VI})$ to capture electrons in the photocatalytic reduction of $\mathrm{Cr}(\mathrm{VI})$ to avoid the photo-corrosion of $\mathrm{Ag}_{2} \mathrm{CO}_{3}$, which can be proved from the integrity of the material before and after four cycles and XPS spectrum before and after photocatalytic $\mathrm{Cr}(\mathrm{VI})$ reduction (Fig. 9b and Fig. S11). Subsequently, the holes on the VB of $\mathrm{Ag}_{2} \mathrm{CO}_{3}$ can directly oxidize organic dyes and also oxidize the $\mathrm{H}_{2} \mathrm{O}$ or $-\mathrm{OH}$ molecules to form $\bullet \mathrm{OH}$, which then participates in the photocatalytic degradation of organic dyes, because the $\mathrm{VB}$ potential ( $3.35 \mathrm{eV}$ vs NHE) is greater than the $\mathrm{H}_{2} \mathrm{O} / \mathrm{HO}$. poten- 
tial (2.40 eV vs NHE) [64]. The photocatalytic mechanism of the UAC-X composites shows that photo-induced holes are also contributors to the degradation process of organic dyes. In the oxidation-reduction reaction of the UAC-X composites, the effective separation of holes and photo-induced electrons in the formed Z-scheme heterojunction contributes to the improved photocatalytic performance.

$$
\begin{gathered}
\mathrm{O}_{2}+\mathrm{e}^{-} \rightarrow \bullet \mathrm{O}_{2}^{-} \\
\bullet \mathrm{O}_{2}^{-}+\mathrm{Cr}(\mathrm{VI}) \rightarrow \mathrm{Cr}(\mathrm{V})+\mathrm{O}_{2}
\end{gathered}
$$

\section{Conclusions}

The UAC- $X$ heterojunction with enhanced photocatalytic properties was successfully prepared by a simple ion-exchange-solution method. The morphology and structure of the UAC- $X$ composites were characterized by FTIR, PXRD, SEM, TEM, HRTEM, UV-Vis DRS, and XPS. The photocatalytic activity of the UAC- $X$ composites for $\mathrm{Cr}(\mathrm{VI})$ reduction is better than that of pure $\mathrm{Ag}_{2} \mathrm{CO}_{3}$ and $\mathrm{UiO}-66-\mathrm{NH}_{2}$ under visible light irradiation. Especially for UAC-100, the ideal effect can be achieved with less UiO-66- $\mathrm{NH}_{2}$ dosage. PL analysis, electrochemistry measurement, capture of active substances, and ESR spectra demonstrated that the reduction enhancement of $\mathrm{Cr}(\mathrm{VI})$ is due to the faster separation of photo-induced electrons and holes and the reduction of $\mathrm{O}_{2^{-}}$over the interface of $\mathrm{Z}$-scheme heterostructure. The effects of $\mathrm{pH}$ value, foreign ions, and small organic acids on the reduction of $\mathrm{Cr}(\mathrm{VI})$ and the organic dye oxidation properties of UAC-100 were also investigated. The presence of organic matters in the reaction system can enhance the photocatalytic $\mathrm{Cr}(\mathrm{VI})$ reduction performance. In addition, UAC-100 exhibits excellent photocatalytic oxidation properties for RhB, MO, CR, and MB due to the generation of $\mathrm{h}^{+}, \mathrm{HO}$, and $\cdot \mathrm{O}_{2}{ }^{-}$with oxidizing properties under visible light. It is worth noting that UAC-100 had excellent reusability and stability in the experiment of photocatalytic reduction of $\mathrm{Cr}(\mathrm{VI})$. This work showed that the combination of UiO-66- $\mathrm{NH}_{2}$ and $\mathrm{Ag}_{2} \mathrm{CO}_{3}$ can enhance the photocatalytic efficiency, which might be used in water treatment. We will carry out further work to address the photo-corrosion of $\mathrm{Ag}_{2} \mathrm{CO}_{3}$, especially during the oxidative degradation toward organic pollutants.

\section{Acknowledgments}

This work was supported by the National Natural Science Foundation of China (51878023, 51578034), Great Wall Scholars Training Program Project of Beijing Municipality Universities (CIT\&TCD20180323), Project of Construction of Innovation Teams and Teacher Career Development for Universities and Colleges Under Beijing Municipality (IDHT20170508), Beijing Talent Project (2018A35), and BUCEA Post Graduate Innovation Project (PG2019039).

\section{References}

[1] H. Dong, J. Deng, Y. Xie, C. Zhang, Z. Jiang, Y. Cheng, K. Hou, G. Zeng, J. Hazard. Mater., 2017, 332, 79-86.

[2] W. Huang, N. Liu, X. Zhang, M. Wu, L. Tang, Appl. Surf. Sci., 2017, 425, 107-116.

[3] J. J. Testa, M. A. A. Grela, M. I. Litter, Environ. Sci. Technol., 2004, 38,

\section{Graphical Abstract}

Chin. J. Catal., 2019, 40: 1912-1923 doi: S1872-2067(19)63433-9

\section{Facile fabrication and enhanced photocatalytic performance of visible light responsive UiO-66- $\mathrm{NH}_{2} / \mathrm{Ag}_{2} \mathrm{CO}_{3} \mathrm{Composite}$}

Yun-Cai Zhou, Xue-Yan Xu, Peng Wang, Huifen Fu, Chen Zhao, Chong-Chen Wang *

Beijing University of Civil Engineering and Architecture

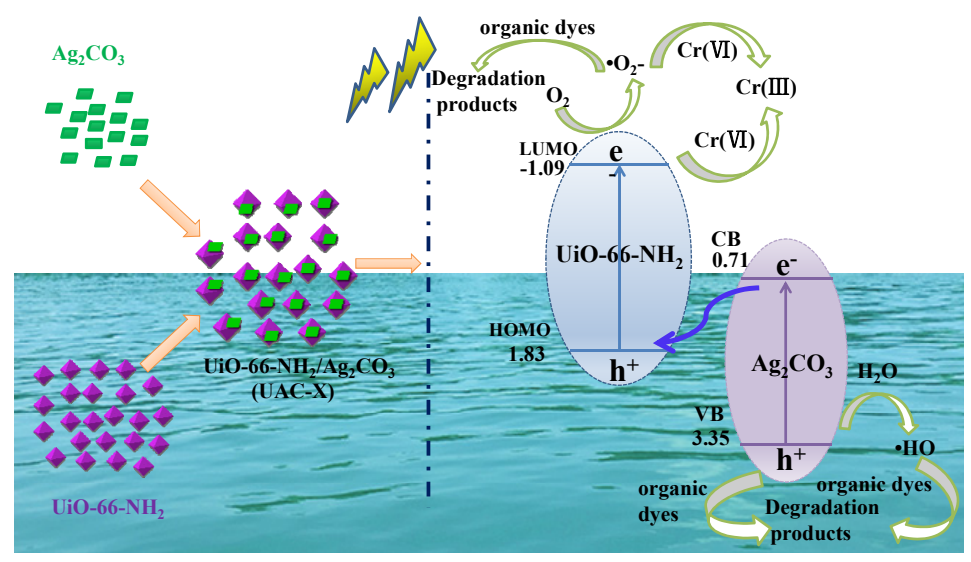

The UiO-66- $\mathrm{NH}_{2} / \mathrm{Ag}_{2} \mathrm{CO}_{3}$ composite (UAC-X) displayed outstanding photocatalytic activity due to the effective separation of photo-induced electrons and holes over the composite, which was contributed to the formed direct Z-scheme heterojunctions. 
1589-1594.

[4] Y. Zhang, M. Xu, H. Li, H. Ge, Z. Bian, Appl. Catal. B, 2018, 226, 213-219.

[5] Y. Xing, X. Chen, D. Wang, Environ. Sci. Technol., 2007, 41, 1439-1443.

[6] B. Galan, D. Castaneda, I. Ortiz, Water Res., 2005, 39, 4317-4324.

[7] C. Lei, X. Zhu, B. Zhu, C. Jiang, Y. Le, J. Yu, J. Hazard. Mater., 2017, 321, 801-811.

[8] G. Pugazhenthi, S. Sachan, N. Kishore, A. Kumar, J. Membr. Sci., 2005, 254, 229-239.

[9] I. Heidmann, W. Calmano, J. Hazard. Mater., 2008, 152, 934-941.

[10] R. Liang, F. Jing, L. Shen, N. Qin, L. Wu, J. Hazard. Mater., 2015, 287, 364-372.

[11] L. B. Khalil, W. E. Mourad, M. W. Rophael, Appl. Catal. B, 1998, 17, 267-273.

[12] C.E. Barrera-Diaz, V. Lugo-Lugo, B. Bilyeu, J. Hazard. Mater., 2012, 223-224, 1-12.

[13] H. Zhao, Q. Xia, H. Xing, D. Chen, H. Wang, ACS Sustain. Chem. Eng., 2017, 5, 4449-4456.

[14] V. Vaiano, O. Sacco, D. Sannino, P. Ciambelli, Appl. Catal. B, 2015, 170-171, 153-161.

[15] Z. Wu, X. Yuan, J. Zhang, H. Wang, L. Jiang, G. Zeng, ChemCatChem, 2017, 9, 41-64.

[16] Z. Sha, H. S. Chan, J. Wu, J. Hazard. Mater., 2015, 299, 132-140.

[17] H. Wang, X. Yuan, Y. Wu, G. Zeng, X. Chen, L. Leng, Z. Wu, L. Jiang, H. Li, J. Hazard. Mater., 2015, 286, 187-194.

[18] C. Chen, W. Ma, J. Zhao, Chem. Soc. Rev, 2010, 39, 4206-4219.

[19] H. Wang, L. Zhang, Z. Chen, J. Hu, S. Li, Z. Wang, J. Liu, X. Wang, Chem. Soc. Rev, 2014, 43, 5234-5244.

[20] J. Schneider, M. Matsuoka, M. Takeuchi, J. Zhang, Y. Horiuchi, M. Anpo, D.W. Bahnemann, Chem. Rev., 2014, 114, 9919-9986.

[21] C. Yu, Q. Fan, Y. Xie, J. Chen, Q. Shu, J. C. Yu, J. Hazard. Mater., 2012, 237-238, 38-45.

[22] Q. Xiang, J. Yu, M. Jaroniec, J. Am. Chem. Soc., 2012, 134, 6575-6578.

[23] Y. Feng, H. Li, L. Ling, S. Yan, D. Pan, H. Ge, H. Li, Z. Bian, Environ. Sci. Technol., 2018, 52, 7842-7848.

[24] H. Ye, Y. Liu, S. Chen, H. Wang, Z. Liu, Z. Wu, Chin. J. Catal., 2019, 40, 631-637.

[25] Y. Feng, L. Ling, J. Nie, K. Han, X. Chen, Z. Bian, H. Li, Z. L. Wang, ACS Nano, 2017, 11, 12411-12418.

[26] C. Yu, L. Wei, J. Chen, Y. Xie, W. Zhou, Q. Fan, Ind. Eng. Chem. Res., 2014, 53, 5759-5766.

[27] C. Yu, G. Li, S. Kumar, K. Yang, R. Jin, Adv. Mater., 2014, 26, 892-898.

[28] S. Song, B. Cheng, N. Wu, A. Meng, S. Cao, J. Yu, Appl. Catal. B, 2016, 181, 71-78.

[29] S. Li, X. Wang, Q. He, Q. Chen, Y. Xu, H. Yang, M. Lü, F. Wei, X. Liu, Chin. J. Catal., 2016, 37, 367-377.

[30] H. Yu, W. Chen, X. Wang, Y. Xu, J. Yu, Appl. Catal. B, 2016, 187, 163-170.

[31] C. Dong, K.-L. Wu, X.-W. Wei, X.-Z. Li, L. Liu, T.-H. Ding, J. Wang, Y. Ye, CrystEngComm, 2014, 16, 730-736.

[32] J. Meng, Q. Chen, J. Lu, H. Liu, ACS Appl. Mater. Interfaces, 2019, 11, 550-562.

[33] A. Crake, K. C. Christoforidis, A. Kafizas, S. Zafeiratos, C. Petit, Appl. Catal. B, 2017, 210, 131-140.

[34] Y. Su, Z. Zhang, H. Liu, Y. Wang, Appl. Catal. B, 2017, 200, 448-457.

[35] R. Wang, L. Gu, J. Zhou, X. Liu, F. Teng, C. Li, Y. Shen, Y. Yuan, Adv. Mater. Interfaces, 2015, 2, 1500037.

[36] C. Gomes Silva, I. Luz, F. X. Llabres i Xamena, A. Corma, H. Garcia, Chem.-Eur. J., 2010, 16, 11133-11138.
[37] L. Shi, X. Meng, T. Wang, H. Zhang, K. Chang, H. Liu, J. Ye, Adv. Sci., 2015, 2, 1500006.

[38] C.-C. Wang, X.-D. Du, J. Li, X.-X. Guo, P. Wang, J. Zhang, Appl. Catal. B, 2016, 193, 198-216.

[39] X.-H. Yi, F.-X. Wang, X.-D. Du, P. Wang, C.-C. Wang, Appl. Organomet. Chem., 2019, 33, 1-11.

[40] L. Shen, S. Liang, W. Wu, R. Liang, L. Wu, Dalton Trans., 2013, 42, 13649-13657.

[41] Q. Xia, B. Huang, X. Yuan, H. Wang, Z. Wu, L. Jiang, T. Xiong, J. Zhang, G. Zeng, H. Wang, J. Colloid Interface Sci., 2018, 530, 481-492.

[42] C.-C. Wang, J.-R. Li, X.-L. Lv, Y.-Q. Zhang, G. Guo, Energy Environ. Sci., 2014, 7, 2831-2867.

[43] Q. Liang, M. Zhang, Z. Zhang, C. Liu, S. Xu, Z. Li, J. Alloys Compd., 2017, 690, 123-130.

[44] X.-H. Yi, F.-X. Wang, X.-D. Du, H. Fu, C.-C. Wang, Polyhedron, 2018, 152, 216-224.

[45] H. Li, S. Yao, H.-L. Wu, J.-Y. Qu, Z.-M. Zhang, T.-B. Lu, W. Lin, E.-B. Wang, Appl. Catal. B, 2018, 224, 46-52.

[46] D. Guo, R. Wen, M. Liu, H. Guo, J. Chen, W. Weng, Appl. Organomet. Chem., 2015, 29, 690-697.

[47] D. Azarifar, R. Ghorbani-Vaghei, S. Daliran, A. R. Oveisi, ChemCatChem, 2017, 9, 1992-2000.

[48] J.-J. Zhou, R. Wang, X.-L. Liu, F.-M. Peng, C.-H. Li, F. Teng, Y.-P. Yuan, Appl. Surf. Sci., 2015, 346, 278-283.

[49] N. Zhang, X. Zhang, C. Gan, J. Zhang, Y. Liu, M. Zhou, C. Zhang, Y. Fang, J. Photochem. Photobiol. A, 2019, 376, 305-315.

[50] X.-Y. Xu, C. Chu, H. Fu, X.-D. Du, P. Wang, W. Zheng, C.-C. Wang, Chem. Eng. J., 2018, 350, 436-444.

[51] X.-Y. Xu, J. Zhang, X. Zhao, H. Fu, C. Chu, P. Wang, C.-C. Wang, ACS Appl. Nano Mater., 2019, 2, 418-428.

[52] H. R. Abid, J. Shang, H.-M. Ang, S. Wang, Int. J. Smart Nano Mater., 2013, 4, 72-82.

[53] J. Yang, Y. Dai, X. Zhu, Z. Wang, Y. Li, Q. Zhuang, J. Shi, J. Gu, J. Mate. Chem. A, 2015, 3, 7445-7452.

[54] Y. Ma, Z. Wang, X. Xu, J. Wang, Chin. J. Catal., 2017, 38, 1956-1969.

[55] J. Liu, B. Cheng, J. Yu, Phys. Chem. Chem. Phys., 2016, 18, 31175-31183.

[56] D. K. Padhi, K. Parida, J. Mater. Chem. A, 2014, 2, 10300-10312.

[57] B. Sun, E. P. Reddy, P. G. Smirniotis, Environ. Sci. Technol., 2005, 39, 6251-6259.

[58] A. Liu, C. C. Wang, C. Z. Wang, H. F. Fu, W. Peng, Y. L. Cao, H. Y. Chu, A. F. Du, J. Colloid Interface Sci., 2018, 512, 730-739.

[59] X. Zhou, C. Hu, X. Hu, T. Peng, J. Qu, J. Phys. Chem. C, 2010, 114, 2746-2750.

[60] N. Fiol, C. Escudero, I. Villaescusa, Bioresource Technol., 2008, 99, 5030-5036.

[61] L. Shen, R. Liang, M. Luo, F. Jing, L. Wu, Phys. Chem. Chem. Phys., 2015, 17, 117-121.

[62] L. Shen, W. Wu, R. Liang, R. Lin, L. Wu, Nanoscale, 2013, 5, 9374-9382.

[63] L. Shen, L. Huang, S. Liang, R. Liang, N. Qin, L. Wu, RSC Adv., 2014 4, 2546-2549.

[64] F. Chen, Q. Yang, Y. Wang, F. Yao, Y. Ma, X. Huang, X. Li, D. Wang, G. Zeng, H. Yu, Chem. Eng. J., 2018, 348, 157-170.

[65] M. Xu, Y. Chen, J. Qin, Y. Feng, W. Li, W. Chen, J. Zhu, H. Li, Z. Bian, Environ. Sci. Technol., 2018, 52, 13879-13886.

[66] K. He, J. Xie, X. Luo, J. Wen, S. Ma, X. Li, Y. Fang, X. Zhang, Chin. J. Catal., 2017, 38, 240-252.

[67] W. Fa, P. Wang, B. Yue, F. Yang, D. Li, Z. Zheng, Chin. J. Catal., 2015, 36, 2186-2193.

[68] Q. Liang, S. Cui, J. Jin, C. Liu, S. Xu, C. Yao, Z. Li, Appl. Surf. Sci., 2018, 
456, 899-907.

[69] X. Li, J. Yu, M. Jaroniec, X. Chen, Chem. Rev., 2019, 119, 3962-4179. [70] K. Qi, B. Cheng, J. Yu, W. Ho, Chin. J. Catal., 2017, 38, 1936-1955.

[71] X. Li, J. Xie, C. Jiang, J. Yu, P. Zhang, Front. Environ. Sci. Eng., 2018, $12,1-32$.
[72] G. Gebreslassie, P. Bharali, U. Chandra, A. Sergawie, P. K. Baruah, M. R. Das, E. Alemayehu, Appl. Organomet. Chemi., 2019, e5002.

[73] J. C. Wang, J. Ren, H. C. Yao, L. Zhang, J. S. Wang, S. Q. Zang, L. F. Han, Z. J. Li, J. Hazard. Mater., 2016, 311, 11-19.

[74] X. Hu, H. Ji, F. Chang, Y. Luo, Catal. Today, 2014, 224, 34-40.

\title{
UiO-66- $\mathrm{NH}_{2} / \mathrm{Ag}_{2} \mathrm{CO}_{3}$ 复合物简易制备及其在可见光驱动下的高效光催化性能
}

\author{
周云彩, 徐雪艳, 王 鹏, 付会芬, 赵 晨, 王崇臣* \\ 北京建筑大学建筑结构与环境修复功能材料北京重点实验室, 北京100044
}

摘要: 近年来, 金属-有机骨架 $(\mathrm{MOFs})$ 作为一种多相光催化剂被越来越多地应用于光催化分解水制氢、还原 $\mathrm{CO}_{2}$ 、还原 $\mathrm{Cr}(\mathrm{VI})$ 和降解环境有机污染物. 尽管MOFs 在光催化领域表现优异, 但是仍然面临一些问题, 例如多数MOFs材料仅在紫外 线激发下才能表现出光催化活性, 多数MOFs 材料导电性不高、水稳定性欠佳及光生电子和空穴容易复合等. 为此, 与一些 窄带隙半导体光催化剂构建复合物是增强MOFs光催化性能的一个有效策略.

本文采用简单的原位离子交换沉积法, 以UiO-66- $\mathrm{NH}_{2}$ 和 $\mathrm{AgNO}_{3}$ 为前驱体在室温下快速制备了一系列具直接Z型异质 结的UiO-66- $\mathrm{NH}_{2} / \mathrm{Ag}_{2} \mathrm{CO}_{3}$ 复合物(记为UAC- $X$, 其中 $X=20 、 50 、 100 、 150$ 和 200 , 代表UiO-66- $\mathrm{NH}_{2}$ 在复合物中的含量). 采用 傅里叶变换红外光谱(FTIR)、粉末X射线衍射(PXRD)、扫描电镜(SEM)、透射电镜(TEM)、高倍透射电镜(HRTEM)、紫外 -可见漫反射(UV-Vis DRS)和X射线光电子能谱(XPS)等技术对UAC- $X$ 复合物的形貌和结构进行了表征. 研究了UAC- $X$ 在 可见光照射下光催化还原六价铬 $(\mathrm{Cr}(\mathrm{VI}))$ 和UAC-100降解有机染料的性能. 探究了不同 $\mathrm{pH}(\mathrm{pH}=2 、 3 、 4 、 6$ 和 8$)$ 、不同小 分子有机酸(柠檬酸、酒石酸和草酸)及共存离子(自来水和地表水中的离子)对光催化还原 $\mathrm{Cr}(\mathrm{VI})$ 的影响.

结果表明, PXRD谱图显示UAC- $X$ 的衍射峰位置分别与UiO-66- $\mathrm{NH}_{2}$ 和 $\mathrm{Ag}_{2} \mathrm{CO}_{3}$ 峰位置完全吻合. SEM、TEM和HRTEM 图片证明在UAC- $X$ 复合物中 $\mathrm{Ag}_{2} \mathrm{CO}_{3}$ 附着在 UiO-66- $\mathrm{NH}_{2}$ 表面. 光照 $50 \mathrm{~min}$ 后, $\mathrm{UAC}-X$ 复合物还原 $\mathrm{Cr}(\mathrm{VI})$ 的效率(UAC-20和 UAC-50分别为 $68 \%$ 和 $86 \%$, UAC-100、UAC-150和UAC-200为 $100 \%$ 均高于UiO-66- $\mathrm{NH}_{2}(19 \%)$ 和 $\mathrm{Ag}_{2} \mathrm{CO}_{3}(8.0 \%)$. UAC- $X$ 复合 物中UiO-66- $\mathrm{NH}_{2}$ 含量增加(比如UAC-20、UAC-50和UAC-100)导致其光催化 $\mathrm{Cr}(\mathrm{VI})$ 活性增强, 其原因在于比表面积增大, 且 表面增强的正电荷对 $\mathrm{Cr}_{2} \mathrm{O}_{7}{ }^{2-}$ 吸附能力增强, 最终提升了其光催化效率.

不同 $\mathrm{pH}$ 值下的光催化实验结果表明: 酸性条件下光催化效率远优于碱性条件, 这是因为在酸性条件下充足的 $\mathrm{H}^{+}$和表 面正电性有利于 $\mathrm{Cr}(\mathrm{VI})$ 还原为 $\mathrm{Cr}(\mathrm{III})$; 在碱性条件下, UAC-100表面呈负电性与 $\mathrm{CrO}_{4}{ }^{2-}$ 发生排斥, 且形成的 $\mathrm{Cr}(\mathrm{OH})_{3}$ 沉淀会遮 盖催化剂表面活性位点, 导致光催化效率下降. 反应溶液中的共存离子也会影响光催化效率: 自来水中的无机离子可在一 定程度上抑制 $\mathrm{UAC}-100$ 对 $\mathrm{Cr}(\mathrm{VI})$ 的光催化效率; 湖水中存在的少量有机物可消耗空穴而减弱共存无机离子对 $\mathrm{Cr}(\mathrm{VI})$ 还原效 率的负面影响. 向无共存离子存在的模拟废水体系中加入酒石酸、柠檬酸和草酸等小分子有机酸时, UAC-100作为光催化 剂还原 $\mathrm{Cr}(\mathrm{VI})$ 的速率和效率显著提高, 这是因为小分子有机物可有效捕捉空穴, 加强光生电子和空穴的分离. 光致发光分 析、电化学分析、电子自旋共振 (ESR) 和活性物质捕获实验显示, $\mathrm{UAC}-100$ 中 $\mathrm{Ag}_{2} \mathrm{CO}_{3}$ 导带 $(\mathrm{CB})$ 上的光生电子转移至 UiO-66- $\mathrm{NH}_{2}$ 最高已占轨道(HOMO), 表明在UAC-100复合物中形成了直接Z型异质结, 提高了光生电子和空穴的分离效率, 最终加强了光催化还原 $\mathrm{Cr}(\mathrm{VI})$ 的活性. 同时, UAC-100经过4次光催化循环实验后其还原 $\mathrm{Cr}(\mathrm{VI})$ 效率仍然可达 $99 \%$, 且 PXRD 谱图未见明显变化, 表明UAC-100具有稳定性和重复利用性. 综上, $\mathrm{UiO}-66-\mathrm{NH}_{2} / \mathrm{Ag}_{2} \mathrm{CO}_{3}$ 是一种具有应用前景的高效复合 型光催化剂.

关键词: 金属-有机骨架; 碳酸银; 六价铬; 光催化; 反应机理

收稿日期: 2019-05-01. 接受日期: 2019-06-26. 出版日期: 2019-12-05.

*通讯联系人. 电话/传真: (010)61209186; 电子信箱: wangchongchen@bucea.edu.cn

基金来源：国家自然科学基金(51878023，51578034); 北京市属高等学校长城学者培养计划(CIT\&TCD20180323); 北京市属高等 学校创新团队建设与教师职业发展计划(IDHT20170508); 北京市百千万人才工程(2018A35); 北京建筑大学研究生创新项目 (PG2019039).

本文的电子版全文由Elsevier出版社在ScienceDirect上出版(http://www.sciencedirect.com/science/journal/18722067). 